\title{
Macrofabric and grain size analysis of moraines and other till deposits in the Serra da Estrela Mountains, central Portugal
}

João Bessa Santos , Gonçalo Vieira , Javier Santos-González , Barbara Woronko \& José María Redondo-Vega

To cite this article: João Bessa Santos, Gonçalo Vieira, Javier Santos-González, Barbara Woronko \& José María Redondo-Vega (2020): Macrofabric and grain size analysis of moraines and other till deposits in the Serra da Estrela Mountains, central Portugal, Physical Geography, DOI: 10.1080/02723646.2020.1838136

To link to this article: https://doi.org/10.1080/02723646.2020.1838136

\section{Published online: 26 Oct 2020.}

Submit your article to this journal $\square$

View related articles

View Crossmark data $\asymp$ 


\title{
Macrofabric and grain size analysis of moraines and other till deposits in the Serra da Estrela Mountains, central Portugal
}

\author{
João Bessa Santos ${ }^{a}$, Gonçalo Vieira (iD ${ }^{b}$, Javier Santos-González (iD c, \\ Barbara Woronko ${ }^{d}{ }^{d}$ and José María Redondo-Vega ${ }^{c}$ \\ aDepartment of Geology, San Jose State University, San Jose, CA USA; 'benter of Geographical Studies, \\ Institute of Geography and Spatial Planning, University of Lisbon, Lisboa, Portugal; 'Department of \\ Geography and Geology, University of León, León, Spain; 'Faculty of Geology, University of Warsaw, \\ Warsaw, Poland
}

\begin{abstract}
Till macrofabric and grain-size analysis of glacial diamictons and landforms present in several valleys of the Serra da Estrela Mountains in central Portugal were used to interpret till types and to reconstruct the glacial paleoprocess history of this mountainous region. Supraglacial melt-out and flow tills are dominant in this range. Supraglacial melt-out tills, representative of periods of glacial stability and stagnation followed by recession, present weaker fabric data and coarser, poorly sorted sediments. Flow tills, mainly representative of glacial stability followed by recession, present crude layering, and soft-sediment deformation structures with moderate fabric data and coarser to fine, poorly sorted sediments. Glacial diamictons affected by post-glacial paraglacial activity in the form of landslides were also observed in three valleys. These present weaker to moderate fabric data and coarser, poorly sorted sediments. These glacial diamictons and landforms are of particular importance in the reconstruction of the glacial dynamics and history of the Serra da Estrela Mountains due to a scarcity of chronological data based on absolute dating methods. These mountains also represent the southernmost Atlantic range in Europe where significant glaciation took place, which makes it an interesting area to investigate mountain glacial dynamics in low elevation humid Atlantic coastal ranges and compare it with other Atlantic ranges.
\end{abstract}

\section{ARTICLE HISTORY}

Received 4 April 2020

Accepted 25 August 2020

\section{KEYWORDS}

Glacial geomorphology; till fabric; grain size; Serra da Estrela Mountains; Portugal

\section{Introduction}

Research in glacial diamictons is important, as it is difficult to observe processes occurring under modern glaciers and ice sheets. Thus, landscapes and sediments that are the product of past glaciations can provide insight into processes that are occurring beneath modern glaciers (Benn \& Evans, 1998).

Glacial sediments of all sizes are transported in, under, and on a glacier and can be deposited at the ice margin in different ways (Benn \& Evans, 1998; Dowdeswell \& Sharp, 1986; Easterbrook, 1999; Evans et al., 2010; Johnson, 1990; Lawson, 1982). Glacial deposition may involve a series of different processes such as fluvial, lacustrine, marine, 
aeolian, and mass wasting (Johnson, 1990). However, deposition by the ice itself (till deposition) is generally the dominant process in the genesis of glacial diamictons with the sediment being usually very poorly sorted and containing a wide range of particle sizes. The differences in the character and structure of many glacial diamictons has led research in glacial geomorphology and geology to place greater emphasis on studies of glacial sedimentology (Benn \& Evans, 1998; Li et al., 2006; Santos et al., 2015, 2017).

Amongst the methods used to understand the genesis of glacial diamictions and landforms is the examination of their sedimentological history and internal structure through a study of the dip and orientation of enclosed pebbles (Andrews, 1971; Benn \& Evans, 1998) and through a calculation of the degree of sediment sorting (Nichols, 1999; Santos et al., 2017). The successful usage of till macrofabric and grain size analysis in the study of both ancient and modern glacial and mass wasting landforms and sediments has been reported by González-Gutiérrez et al. (2019), Johnson (1990), Lawson (1981, 1982), Lachniet et al. (1999), Li et al. (2006), Millar (2006), Santos and Cunha (2012), Santos et al. (2013, 2015, 2017), and Santos-González et al. (2013a).

This paper investigates the depositional history of several late Quaternary glacial diamictons and moraines present in the Serra da Estrela Mountains in central Portugal, an area where systematic sedimentological analysis of moraines and diamictons requires more detailed investigation (Daveau, 1971; Migón \& Vieira, 2014; Vieira, 1998, 1999, 2004; Vieira et al., 2001a, 2003). This research is particularly important because of the geographic location of the Serra da Estrela mountains. It is the southernmost Atlantic range in southwest Europe where significant glaciation took place. On average the Serra da Estrela Mountains have modest elevations (highest elevation is 1993 m.a.s.l.) when compared with other glaciated mountain ranges in the Iberian Peninsula. This occurred because the paleo-ELA was around 1650 m.a.s.l. (Vieira, 2008), a low value for the Iberian Peninsula (Santos-González et al., 2013b). The proximity of the Northern Atlantic Ocean (around 93 kilometres) and its influence in the amount of snowfall delivered to these mountains, together with a large plateau between 1400 and 1993 m.a.s.l., have allowed glaciers to rapidly respond to fluctuations in climate (Vieira, 2008; Vieira \& Nieuwendam, 2020). These conditions make this range an interesting area to investigate mountain glacial dynamics in low elevation humid Atlantic coastal ranges and compare it with other Atlantic ranges. Also, these mountains record the lowest glaciation latitude in Portugal and one of the lowest in the Iberian Peninsula and Europe which reinforces the importance of proximity to the North Atlantic Ocean.

This research is part of a larger study in glacial geomorphology across the glaciated ranges of the western Iberian Peninsula in which comparisons of different glacial deposits are examined.

\section{Study area}

The study area consists of the glaciated valleys of the Serra da Estrela Mountains $\left(40^{\circ} 20\right.$ 'N, $7^{\circ} 35^{\prime} \mathrm{W}$ ) located in the west-central portion of the Iberian Peninsula (Figure 1). In terms of bedrock geology this range is dominated by Hercynian granites (300 Ma) installed in a marine Precambrian-Cambrian schist-metagreywacke sequence (650-$500 \mathrm{Ma}$ ) (Vieira et al., 2005). Hercynian magmatism resulted in different granitic facies. Coarse-grained porphyritic biotite-muscovite granite in association with granodiorite 


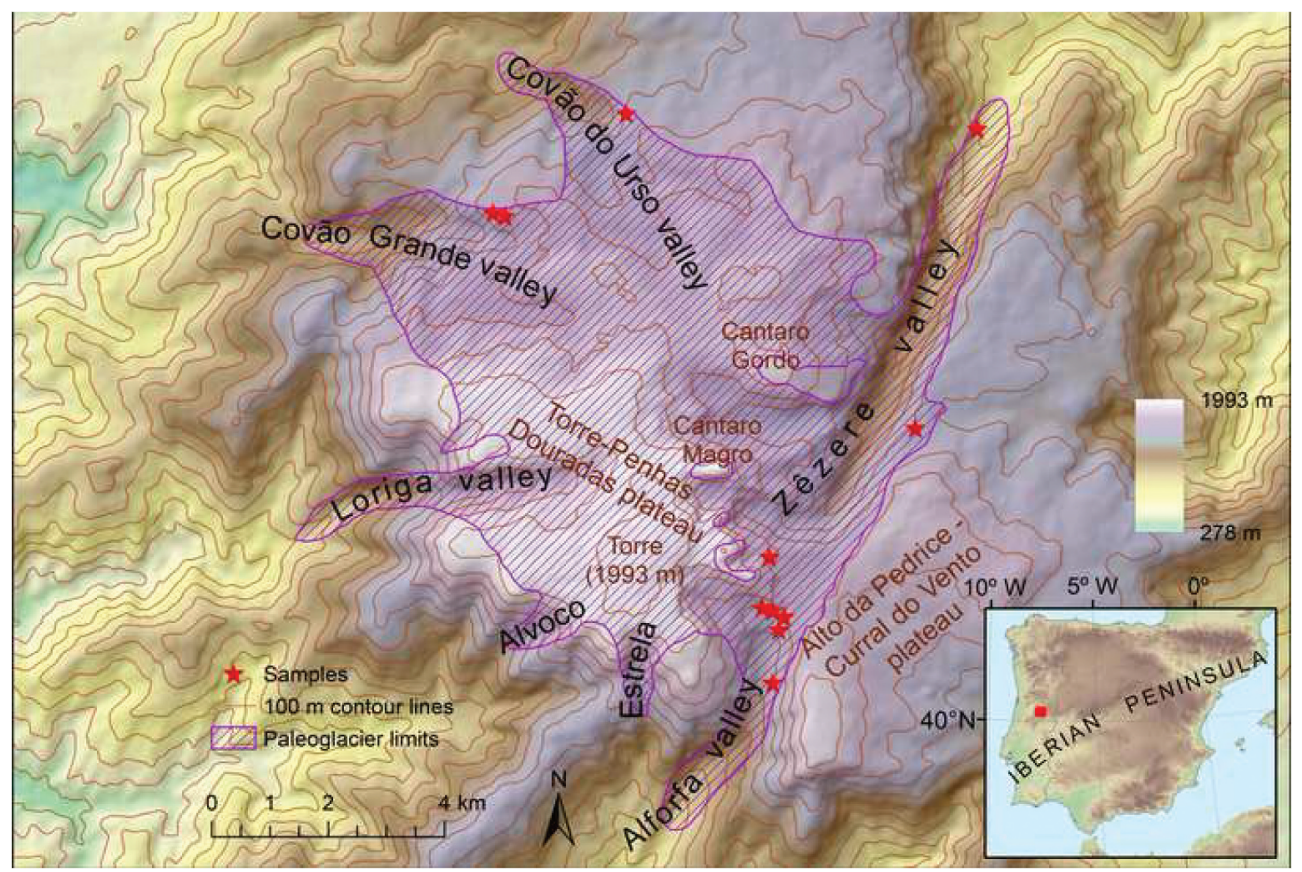

Figure 1. Location map of the study area showing paleo-glacial extents and sample sites. Glacial extent is based on Vieira (2004) and observations during this research.

predominates in the region. In the core of the granitic massif, muscovite granite occurs, forming a zoned pluton structure (Vieira et al., 2005).

During late Hercynian times, a major strike-slip fault system with NNE-SSW and NESW orientations developed and affected the region. In the Mesozoic and Cenozoic, the Hercynian mountain range was eroded, followed by crustal uplift and planation (Vieira et al., 2005). According to Ribeiro (1988), Alpine compressive tectonics reactivated the NNE-SSW and NE-SW Hercynian faults and uplifted the mountain as a horst. The present relief is therefore a result of the Alpine orogeny that uplifted old Variscan/ Hercynian structures during the late Paleogene. This tectonic upheaval would later have a significant influence on glacier development during the late Quaternary.

In terms of topography, two major plateaus divided by the SSW- NNE Alforfa and Zêzere glacial valleys dominate the relief of these mountains (Figure 1). The Torre Penhas Douradas plateau (1993-1450 m.a.s.l.) located in the western side, and the Alto da Pedrice - Curral do Vento plateau, in the eastern side (1760-1450 m.a.s.l.) (Vieira et al., 2005). The Torre - Penhas Douradas plateau records the highest elevation of this range (1993 m.a.s.l. at Alto da Torre). These plateaus display flat surfaces at distinct altitudes and present a few wide valleys with moderate to severe pre and post-glacial fluvial erosion. Mountain peaks are uncommon with the notable exceptions of the Cantaro Magro (1928 m.a.s.l.) and Cantaro Gordo (1875 m.a.s.l.) (Figure 2). During late Quaternary times the Torre - Penhas Douradas plateau functioned as a main zone of accumulation in the genesis of several outlet glaciers that flowed in a number of valleys from an icefield generated in the plateau (Vieira, 2004, 2008; Vieira et al., 2001a). 


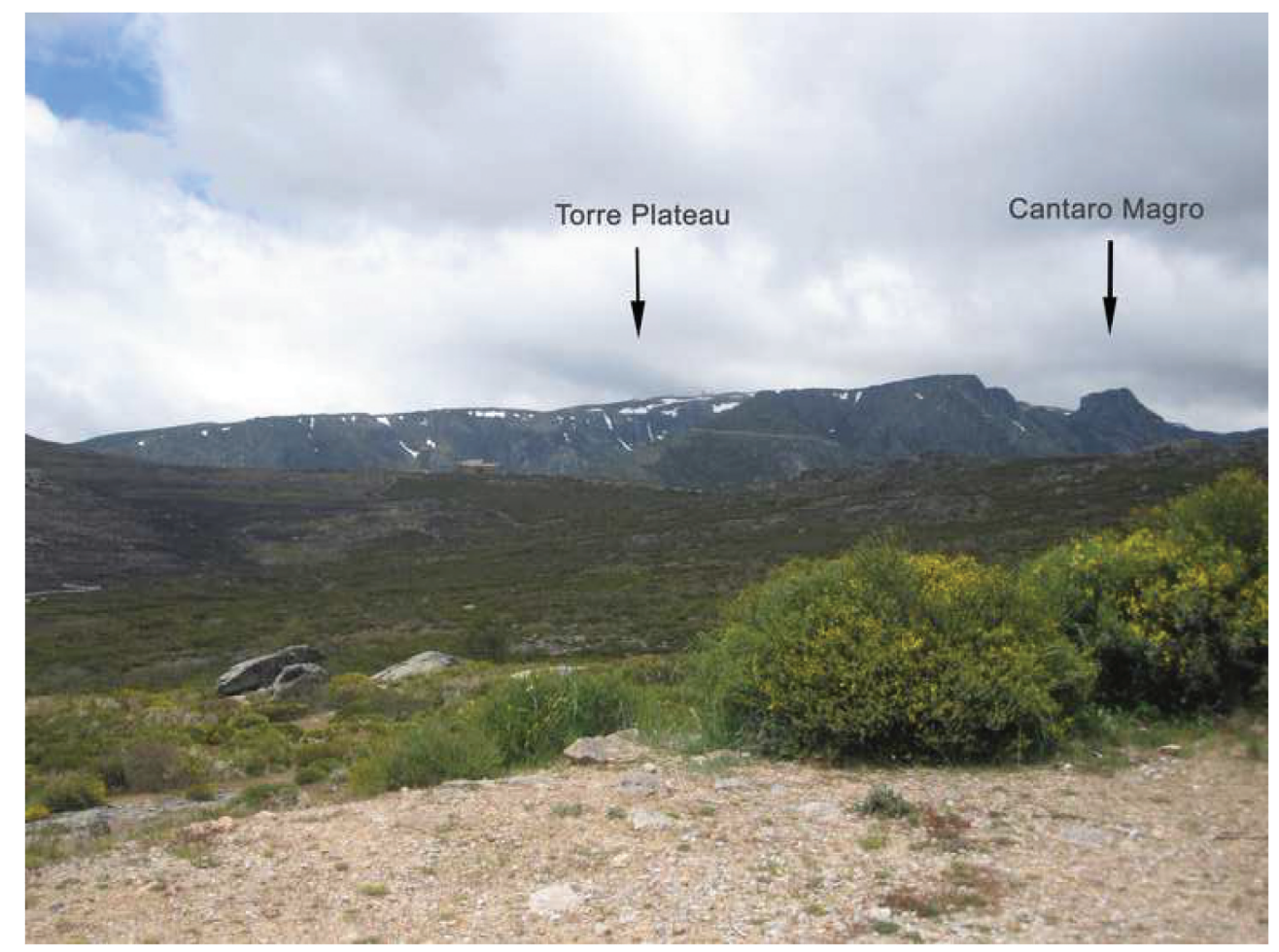

Figure 2. The Torre - Penhas Douradas plateau on the western side of the Serra da Estrela Mountains seen from the Alto da Pedrice - Curral do Vento plateau on the eastern side. The Cantaro Magro peak can be seen on the Torre - Penhas Douradas plateau.

The largest glacial valley in the Serra da Estrela Mountains is the Zêzere valley, home to the largest outlet glacier in the range (Figures 1 and 3). It had an SSW- NNE orientation and an ice tongue over $10 \mathrm{~km}$ in length with the ice-front reaching the present location of the village of Manteigas at ca. 750 m.a.s.l. In some locations ice thickness reached $300 \mathrm{~m}$ (Vieira, 2008). Other important glacial valleys in this range were: the Alforfa valley with an NNE-SSW orientation and home to a smaller outlet glacier $5.8 \mathrm{~km}$ long with ice thickness up to $240 \mathrm{~m}$; the Covão Grande valley with an ESEWNW orientation and home to an outlet glacier approximately $6.2 \mathrm{~km}$ long with ice thickness reaching more than $180 \mathrm{~m}$ in several locations; the Covão do Urso valley with an SE-NW orientation and home to an outlet glacier $7.2 \mathrm{~km}$ long and ice thickness never greater than $240 \mathrm{~m}$; the Loriga valley with an ENE-WSW orientation and home to an outlet glacier $6.7 \mathrm{~km}$ long with ice thickness up to $180 \mathrm{~m}$. The smaller Alvoco and Estrela valleys located in the southwest portion of the range hosted small outlet ice tongues never reaching lengths greater than $2.5 \mathrm{~km}$ with ice thicknesses up to $90 \mathrm{~m}$. Except for the Alvoco and Estrela valleys, all remaining valleys still exhibit well defined glacial U-shaped profiles with the Zêzere valley being the best example (Figure 3).

The Serra da Estrela Mountains are located in the boundary between the Mediterranean-Oceanic climatic zones. Present-day summers are warm and dry, and the wet season lasts from October to May, with a mean annual precipitation around 


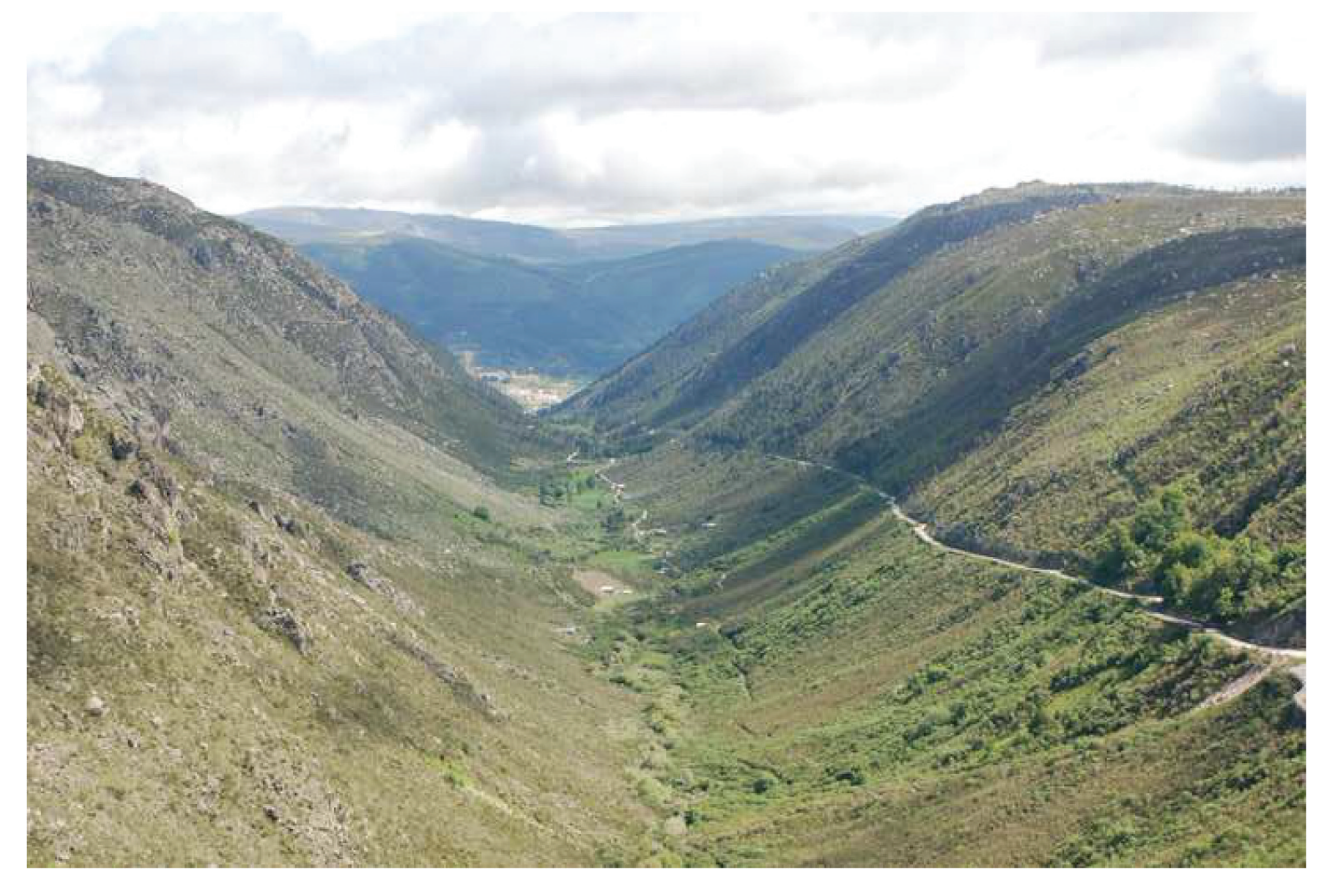

Figure 3. U-shaped profile of the glaciated Zêzere valley with the village of Manteigas in the background.

$2500 \mathrm{~mm}$ in the summit and more than $2000 \mathrm{~mm}$ in the plateaus (Mora, 2010; Vieira et al., 2001a, 2005). The western portion of the mountain faces the Atlantic and presents a larger number of days with rainfall, but a slightly lower total amount than the eastern portion, which in turn experiences a smaller number of days with rain (Daveau et al., 1977). The mean annual temperature is below $7^{\circ} \mathrm{C}$ in locations above $1400 \mathrm{~m}$.a.s.l. and $4^{\circ}$ C for the Torre Plateau (Vieira \& Mora, 1998). Snowfall occurs during the winter with Andrade et al. (1992) suggesting a median of 40 to 50 days with snowfall at 1400-1600 m. a.s.l.

\section{Previous work}

The first reference to the glacial geomorphology of the Serra do Estrela Mountains was made in the nineteenth century by Cabral (1884) in which glacial landforms were identified; however, it was only with Lautensach $(1929,1932)$ ) that glaciation in these mountains was studied in some detail. Daveau (1971) revised Lautensach's ideas and presented a more comprehensive account of the glacial geomorphology of the mountain which included a detailed geomorphic and bedrock geology study describing the location of the ice margin positions and glacial landforms in the major glacial valleys of the range via geomorphologic maps.

Since 1998 research on the glacial geomorphology of the Serra da Estrela Mountains has been the work of Vieira (1998, 1999, 2004, 2008), Vieira et al. (2001a), and (2005)). These authors updated information on ice maximum positions during the local Last 
Glacial Maximum (LGM) and reported the location of newfound glacial landforms and deposits via detailed Quaternary geology mapping. Vieira et al. (2001a) and Palacios et al. (2012) also presented the first tentative maximum ice extent glacial chronologies for these mountains via thermoluminescence dating of fluvioglacial deposits and cosmogenic ${ }^{36} \mathrm{Cl}$ surface exposure dating of moraine boulders and glacially polished outcrops. Palacios et al. (2012) proposed a tentative age between 31 and $26 \mathrm{ka}$ for the local LGM in the Serra da Estrela Mountains. More recently, with the classification of the territory as a UNESCO Global Geopark - the Estrela Geopark, new studies have commenced (Vieira \& Nieuwendam, 2020).

This paper extends the geomorphic work of these authors and adds a detailed sedimentological study of glacial diamictons and moraines in several valleys in order to provide a clearer picture of the ice dynamics during deglaciation. Detailed glacial sedimentological analyses are rare in the western portion of the Iberian Peninsula (González-Gutiérrez et al., 2019), with some exceptions in the Sanabria Mountains (Pérez-Alberti et al., 2011; Santos-González et al., 2015), the western portion of the Cantabrian Mountains (Redondo-Vega et al., 2006; Santos-González, 2012; SantosGonzález et al., 2013a) and the Serra da Peneda-Gerês Mountains (Santos et al., 2015, 2017).

\section{Methodology}

Reconstruction of the processes responsible for the genesis of glacial landforms and deposits was accomplished using standard geomorphic and sedimentological techniques. Identification of glacial landforms and deposits by type, shape, size, orientation, and slope was accomplished in the field via aerial and ground photographs. Till macrofabric (Andrews, 1971; Benn, 1994; Dowdeswell \& Sharp, 1986; Hart, 1994; Johnson, 1990; Li et al., 2006; Mark, 1973) and grain-size analysis (Folk, 1955, 1966; Krumbein, 1934; Nichols, 1999; Udden, 1898; Wentworth, 1922) were the two techniques used to understand their internal sedimentology. Lithology, clast shape, and structure observations were also recorded.

The usage of macrofabric analysis in glacial deposits has been questioned by Bennett et al. (1999) and Carr and Rose (2003), however when used with care and supported by other sedimentological studies, especially with grain-size analysis, they are an important technique in reconstructing palaeoglacial processes and dynamics (Benn \& Evans, 1996; Carlson et al., 2004; Evans et al., 2006, 2010; Karlstrom \& Barendregt, 2001; Larsen et al., 2004).

At eight different sites (Table 1), A-axis fabrics of 25-100 clasts per deposit (25 clasts per sample) were determined. Three to four samples were used on most deposits to reduce the chance of sampling effects. Elongated clasts (long to intermediate axis ratio over 1.5) over $10 \mathrm{~cm}$ were chosen because they respond better to glacier flow and lead to a consistent fabric (Benn \& Evans, 1996; Kjær \& Krüger, 1998). Pebbles were taken from natural and artificial vertical exposures in each analysis, and all pebbles were taken from an area of $<1 \mathrm{~m}^{2}$. In order to avoid any degree of disturbance the upper $50 \mathrm{~cm}$ of every exposure was not sampled (Andrews, 1971). The program of Kamb (1959) on Rockware StereoStat V1.5 was used to plot and contour all data in equal-area nets. These representations provide information on 
Table 1. Eigenvalues, azimuth, and plunge of the Serra da Estrela Mountains' deposit fabrics. The location of the sites can be seen in Figures 1, 5, 9, 12, and 15 .

\begin{tabular}{|c|c|c|c|c|c|c|c|}
\hline \multirow[b]{2}{*}{ Valley/Area } & \multirow[b]{2}{*}{ Exposure } & \multirow[b]{2}{*}{ Unit } & \multirow[b]{2}{*}{ Sample } & \multirow[b]{2}{*}{ S1 } & \multirow[b]{2}{*}{ S3 } & \multicolumn{2}{|c|}{ Eigenvector V1 } \\
\hline & & & & & & Azimuth & Plunge \\
\hline Alforfa Valley Lateral Moraine 1 & 1 & 1 & 1 & 0.5475 & 0.0623 & 35 & 7 \\
\hline Alforfa Valley Lateral Moraine 1 & 1 & 1 & 2 & 0.6140 & 0.0578 & 19 & 10 \\
\hline Alforfa Valley Lateral Moraine 1 & 1 & 1 & 3 & 0.6327 & 0.1491 & 39 & 1 \\
\hline Alforfa Valley Lateral Moraine 1 & 1 & 1 & 4 & 0.4872 & 0.0449 & 336 & 20 \\
\hline \multicolumn{4}{|c|}{ Alforfa Valley Lateral Moraine 1 Exposure 1 Average (100 clasts)* } & 0.5704 & 0.0785 & 21 & 10 \\
\hline Alforfa Valley Lateral Moraine 1 & 2 & 1 & 1 & 0.5781 & 0.0391 & 357 & 7 \\
\hline Alforfa Valley Lateral Moraine 1 & 2 & 1 & 2 & 0.7763 & 0.0212 & 4 & 14 \\
\hline Alforfa Valley Lateral Moraine 1 & 2 & 1 & 3 & 0.5213 & 0.0743 & 48 & 2 \\
\hline Alforfa Valley Lateral Moraine 1 & 2 & 1 & 4 & 0.5055 & 0.0380 & 97 & 16 \\
\hline \multicolumn{4}{|c|}{ Alforfa Valley Lateral Moraine 1 Exposure 2 Average (100 clasts)* } & 0.5953 & 0.0432 & 22 & 10 \\
\hline Alforfa Valley Lateral Moraine 1 & 3 & 1 & 1 & 0.6687 & 0.0521 & 74 & 19 \\
\hline \multicolumn{4}{|c|}{ Alforfa Valley Lateral Moraine 1 Exposure 3 Average (25 clasts)* } & 0.6687 & 0.0521 & 74 & 19 \\
\hline Alforfa Valley Lateral Moraine 2 & 1 & 1 & 1 & 0.6467 & 0.0491 & 56 & 6 \\
\hline Alforfa Valley Lateral Moraine 2 & 1 & 1 & 2 & 0.5814 & 0.0541 & 48 & 8 \\
\hline Alforfa Valley Lateral Moraine 2 & 1 & 1 & 3 & 0.4801 & 0.1077 & 76 & 10 \\
\hline Alforfa Valley Lateral Moraine 2 & 1 & 1 & 4 & 0.6008 & 0.0557 & 13 & 18 \\
\hline \multicolumn{4}{|c|}{ Alforfa Valley Lateral Moraine 2 Exposure 1 Average (100 clasts)* } & 0.5773 & 0.0667 & 50 & 11 \\
\hline Alforfa Mid-Valley Diamicton & 1 & 1 & 1 & 0.6623 & 0.0255 & 210 & 10 \\
\hline Alforfa Mid-Valley Diamicton & 1 & 1 & 2 & 0.5358 & 0.0581 & 144 & 16 \\
\hline Alforfa Mid-Valley Diamicton & 1 & 1 & 3 & 0.6046 & 0.0538 & 103 & 11 \\
\hline \multicolumn{4}{|c|}{ Alforfa Mid-Valley Diamicton Exposure 1 Average (75 clasts)* } & 0.6009 & 0.0458 & 133 & 16 \\
\hline Zêzere Valley Lateral Moraine & 1 & 1 & 1 & 0.6327 & 0.0227 & 318 & 8 \\
\hline Zêzere Valley Lateral Moraine & 1 & 1 & 2 & 0.5731 & 0.0750 & 220 & 2 \\
\hline Zêzere Valley Lateral Moraine & 1 & 1 & 3 & 0.4774 & 0.2141 & 293 & 6 \\
\hline Zêzere Valley Lateral Moraine & 1 & 1 & 4 & 0.6103 & 0.0754 & 306 & 24 \\
\hline \multicolumn{4}{|c|}{ Zêzere Valley Lateral Moraine Exposure 1 Average (100 clasts)* } & 0.5734 & 0.0968 & 303 & 13 \\
\hline Zêzere Valley Recessional Moraine & 1 & 1 & 1 & 0.6686 & 0.0398 & 81 & 12 \\
\hline Zêzere Valley Recessional Moraine & 1 & 1 & 2 & 0.6008 & 0.0536 & 135 & 14 \\
\hline Zêzere Valley Recessional Moraine & 1 & 1 & 3 & 0.6677 & 0.0340 & 113 & 16 \\
\hline Zêzere Valley Recessional Moraine & 1 & 1 & 4 & 0.6689 & 0.0269 & 101 & 19 \\
\hline \multicolumn{4}{|c|}{ Zêzere Valley Recessional Moraine Exposure 1 Average (100 clasts)* } & 0.6515 & 0.0386 & 107 & 16 \\
\hline Zêzere Lower Valley Till & 1 & 1 & 1 & 0.6008 & 0.0698 & 120 & 3 \\
\hline Zêzere Lower Valley Till & 1 & 1 & 2 & 0.6391 & 0.0509 & 220 & 3 \\
\hline Zêzere Lower Valley Till & 1 & 1 & 3 & 0.6626 & 0.0937 & 209 & 10 \\
\hline \multicolumn{4}{|c|}{ Zêzere Lower Valley Till Exposure 1 Average (75 clasts)* } & 0.6342 & 0.0715 & 219 & 6 \\
\hline Covão Grande Valley Lateral Moraine & 1 & 1 & 1 & 0.5993 & 0.1065 & 279 & 10 \\
\hline \multicolumn{4}{|c|}{ Covão Grande Valley Lateral Moraine Exposure 1 Average (25 clasts)* } & 0.5993 & 0.1065 & 279 & 10 \\
\hline Covão Grande Valley Lateral Moraine & 2 & 1 & 1 & 0.7588 & 0.0536 & 111 & 8 \\
\hline \multicolumn{4}{|c|}{ Covão Grande Valley Lateral Moraine Exposure 2 Average (25 clasts)* } & 0.7588 & 0.0536 & 111 & 8 \\
\hline Covão do Urso Valley Lateral Moraine & 1 & 1 & 1 & 0.6399 & 0.0445 & 115 & 13 \\
\hline \multicolumn{4}{|c|}{ Covão do Urso Valley Lateral Moraine Exposure 1 Average (25 clasts)* } & 0.6399 & 0.0445 & 115 & 13 \\
\hline
\end{tabular}

*Averages are taken from all clasts in each site

the nature of the fabric that could be isotropic (no main direction), girdle (points distributed around a circle), or cluster (most of the A-axes clasts show the same orientation).

The eigenvalue method discussed by Mark (1973) was used in the statistical analysis of the data. According to Johnson (1990) and Benn (1994), this method determines three mutually perpendicular axes (eigenvectors V1, V2, and V3), the longest of which (V1) lies in the direction of maximum pebble clustering. The eigenvalues (S1, S2, and S3) describe the degree of concentration about each axis, referred to as the fabric strength; azimuth and plunge values describe the orientation of the V1 eigenvector, which in subglacial deposits typically is similar to the preferred glacial flow direction (Benn, 1994; Evans et al., 2006). 
Lawson (1981), Millar (2006), Santos and Cunha (2012), Santos-González et al. (2013a), Santos et al. $(2015,2017)$ ) used the eigenvalue of pebbles fabrics to describe diamictons in moraines and periglacial colluvium and interpret their genesis. The equilateral or general shape triangle introduced by Benn (1994) was used to plot the eigenvalues. This plots an isotropy index $(\mathrm{I}=\mathrm{S} 3 / \mathrm{S} 1)$ and an elongation index $[\mathrm{E}=1-(\mathrm{S} 2 /$ S1)], which together illustrate the degree of clustering, girdling, or randomness in the fabric. The data were also plotted in the biaxial diagram of Dowdeswell and Sharp (1986), which plots S1 and S3 values.

Grain-size distributions of 22 samples (200 g each) (Table 2) collected from the same eight sites used for pebble-fabric analysis were described using the Wentworth-Udden grain-size classification (Udden, 1898; Wentworth, 1922) and the phi scale of Krumbein (1934). This was undertaken only on the matrix component of the samples, where granules and pebbles $(-2.0 \phi)$ were the coarsest grain size. Thus, all the samples were sieved through a $4.75 \mathrm{~mm}$ sieve prior to performing sieve analysis. Clast analysis was accomplished in the field by determining clast roundness using the classification of Folk (1955).

\section{Glacial geomorphology and sedimentology}

The glacial geomorphology and sedimentology of the Serra da Estrela Mountains is quite rich in spite of the modest size of its glaciated area. Glacial depositional landforms related to the last glacial maximum advance are abundant and well preserved in the Zêzere, Alforfa, Covão Grande, and Covão do Urso glacial valleys. The most common glacial depositional landforms are terminal, lateral, and recessional moraines (Figure 4(a)). They are the product of ice stability and advances that occurred in Late Quaternary times (Daveau, 1971; Vieira, 1999, 2004; Vieira et al., 2005). The shape and morphology of most of these moraines is also very similar. They all present sharp crests with steep to moderate slopes and unweathered large granite boulders, showing that they are still geologically young (Vieira, 1999).

Glacial erosional landforms are also abundant in these mountains with the presence of the typical U-shaped profiles in the Zêzere (Figure 3), Alforfa, Covão Grande, and Covão do Urso glacial valleys. In the upper Zêzere and Alforfa glacial valleys it is possible to observe the best examples of glacial cirques in the entire range (Figure 4(b)). Roches mouttonées and striated rock outcrops, bearing evidence of the power of moving ice, are present throughout the landscape in all glacial valleys of the Serra da Estrela Mountains. Glacial deposits in the study area are for the most part naturally exposed, but some till deposits are exposed due to anthropogenic activity (e.g., roads and trails).

\section{Description and interpretation of the moraines and deposits}

\section{Alforfa valley}

The Alforfa valley with its well-defined U-shaped profile is home to an array of glacial deposits and landforms (Figures 5, 6(a), and 7(a)). Five exposures present in two lateral moraines and a road cut were identified and sampled in the upper and mid portions of this valley (Figures 1 and 5). 
Table 2. Grain size data of the Serra da Estrela Mountains' deposits. The location of the sites can be seen in Figures 1, 5, 9, 12, and 15.

\begin{tabular}{|c|c|c|c|c|c|c|c|c|}
\hline \multirow[b]{2}{*}{ Valley/Area } & \multirow[b]{2}{*}{ Exposure } & \multirow[b]{2}{*}{ Unit } & \multirow[b]{2}{*}{ Sample } & \multicolumn{3}{|c|}{ Grain Size \% } & \multicolumn{2}{|c|}{ Sorting $(\phi)$} \\
\hline & & & & Gravel $^{a}$ & Sand & Mud $^{\mathbf{b}}$ & $\begin{array}{c}\text { Graphic } \\
\text { Mean }\end{array}$ & $\begin{array}{l}\text { Standard } \\
\text { Deviation }\end{array}$ \\
\hline Alforfa Valley Lateral Moraine 1 & 1 & 1 & 1 & 24.00 & 65.90 & 10.10 & 0.88 & 2.25 \\
\hline Alforfa Valley Lateral Moraine 1 & 1 & 1 & 2 & 22.10 & 68.90 & 9.00 & 0.83 & 2.15 \\
\hline $\begin{array}{l}\text { Alforfa Valley Lateral Moraine } 1 \\
\text { Exposure } 1 \text { Average }\end{array}$ & & & & 23.05 & 67.40 & 9.55 & 0.86 & 2.20 \\
\hline Alforfa Valley Lateral Moraine 1 & 2 & 1 & 1 & 20.30 & 69.50 & 10.20 & 0.97 & 2.20 \\
\hline Alforfa Valley Lateral Moraine 1 & 2 & 1 & 2 & 22.20 & 68.40 & 9.40 & 0.88 & 2.18 \\
\hline $\begin{array}{l}\text { Alforfa Valley Lateral Moraine } 1 \\
\text { Exposure } 2 \text { Average }\end{array}$ & & & & 21.25 & 68.95 & 9.80 & 0.93 & 2.19 \\
\hline Alforfa Valley Lateral Moraine 1 & 3 & 1 & 1 & 20.40 & 69.40 & 10.20 & 0.97 & 2.20 \\
\hline Alforfa Valley Lateral Moraine 1 & 3 & 1 & 2 & 20.10 & 70.00 & 9.90 & 0.95 & 2.11 \\
\hline $\begin{array}{l}\text { Alforfa Valley Lateral Moraine } 1 \\
\text { Exposure } 3 \text { Average }\end{array}$ & & & & 20.25 & 69.70 & 10.05 & 0.96 & 2.16 \\
\hline Alforfa Valley Lateral Moraine 2 & 1 & 1 & 1 & 22.10 & 67.40 & 10.50 & 0.97 & 2.23 \\
\hline Alforfa Valley Lateral Moraine 2 & 1 & 1 & 2 & 25.30 & 64.00 & 10.70 & 0.83 & 2.28 \\
\hline $\begin{array}{l}\text { Alforfa Valley Lateral Moraine } 2 \\
\text { Exposure } 1 \text { Average }\end{array}$ & & & & 23.70 & 65.70 & 10.60 & 0.90 & 2.26 \\
\hline Alforfa Mid-Valley Diamicton & 1 & 1 & 1 & 24.60 & 66.80 & 8.60 & 0.72 & 2.14 \\
\hline Alforfa Mid-Valley Diamicton & 1 & 1 & 2 & 22.40 & 68.60 & 9.00 & 0.85 & 2.15 \\
\hline Alforfa Mid-Valley Diamicton & 1 & 1 & 3 & 24.90 & 65.80 & 9.30 & 0.80 & 2.21 \\
\hline $\begin{array}{l}\text { Alforfa Mid-Valley Diamicton } \\
\text { Exposure } 1 \text { Average }\end{array}$ & & & & 23.97 & 67.07 & 8.97 & 0.79 & 2.17 \\
\hline Zêzere Valley Lateral Moraine & 1 & 1 & 1 & 27.70 & 62.50 & 9.80 & 0.70 & 2.26 \\
\hline Zêzere Valley Lateral Moraine & 1 & 1 & 2 & 21.10 & 70.70 & 8.20 & 0.90 & 2.12 \\
\hline $\begin{array}{l}\text { Zêzere Valley Lateral Moraine } \\
\text { Exposure } 1 \text { Average }\end{array}$ & & & & 24.40 & 66.60 & 9.00 & 0.80 & 2.19 \\
\hline Zêzere Valley Recessional Moraine 3 & 1 & 1 & 1 & 26.70 & 65.90 & 7.40 & 0.55 & 2.12 \\
\hline Zêzere Valley Recessional Moraine 3 & 1 & 1 & 2 & 21.00 & 69.20 & 9.80 & 1.02 & 2.19 \\
\hline $\begin{array}{l}\text { Zêzere Valley Recessional Moraine } 3 \\
\text { Exposure } 1 \text { Average }\end{array}$ & & & & 23.85 & 67.55 & 8.60 & 0.79 & 2.16 \\
\hline Zêzere Lower Valley Till & 1 & 1 & 1 & 26.60 & 62.90 & 10.50 & 0.75 & 2.26 \\
\hline Zêzere Lower Valley Till & 1 & 1 & 2 & 23.70 & 66.60 & 9.70 & 0.83 & 2.21 \\
\hline $\begin{array}{l}\text { Zêzere Lower Valley Till Exposure } 1 \\
\text { Average }\end{array}$ & & & & 25.15 & 64.75 & 10.10 & 0.79 & 2.24 \\
\hline Covão Grande Valley Lateral Moraine & 1 & 1 & 1 & 25.30 & 63.60 & 11.10 & 0.87 & 2.28 \\
\hline Covão Grande Valley Lateral Moraine & 1 & 1 & 2 & 24.60 & 63.50 & 11.90 & 0.88 & 2.31 \\
\hline $\begin{array}{l}\text { Covão Grande Valley Lateral Moraine } \\
\text { Exposure } 1 \text { Average }\end{array}$ & & & & 24.95 & 63.55 & 11.50 & 0.88 & 2.30 \\
\hline Covão Grande Valley Lateral Moraine & 2 & 1 & 1 & 25.40 & 66.30 & 8.30 & 0.70 & 2.15 \\
\hline $\begin{array}{l}\text { Covão Grande Valley Lateral Moraine } \\
\text { Exposure } 2 \text { Average }\end{array}$ & & & & 25.40 & 66.30 & 8.30 & 0.70 & 2.15 \\
\hline Covão do Urso Valley Lateral Moraine & 1 & 1 & 1 & 25.90 & 65.00 & 9.10 & 0.73 & 2.19 \\
\hline Covão do Urso Valley Lateral Moraine & 1 & 1 & 2 & 28.90 & 63.00 & 8.10 & 0.55 & 2.16 \\
\hline $\begin{array}{l}\text { Covão do Urso Valley Lateral Moraine } \\
\text { Exposure } 1 \text { Average } \\
\text { Gravel }^{\mathrm{a}}=\text { Pebbles + Granules } \\
\text { Mud }^{\mathbf{b}}=\text { Silt + Clay }\end{array}$ & & & & 27.40 & 64.00 & 8.60 & 0.64 & 2.18 \\
\hline
\end{tabular}

\section{Alforfa valley lateral moraine 1}

Lateral moraine 1 is a lateral-terminal moraine located in the upper and mid portions of the valley (Figures 6(a) and 7(b)). It is the largest and best preserved glacial depositional feature in the Alforfa valley. Three exposures were identified and sampled.

Exposures 1, 2, and 3 are located at 1516, 1533, and 1560 m.a.s.l., respectively, and at 176,193 , and $220 \mathrm{~m}$ above the valley floor. Ice thickness at these locations (based on till observations in these areas) must not have exceeded 176, 193, and $220 \mathrm{~m}$, respectively. 

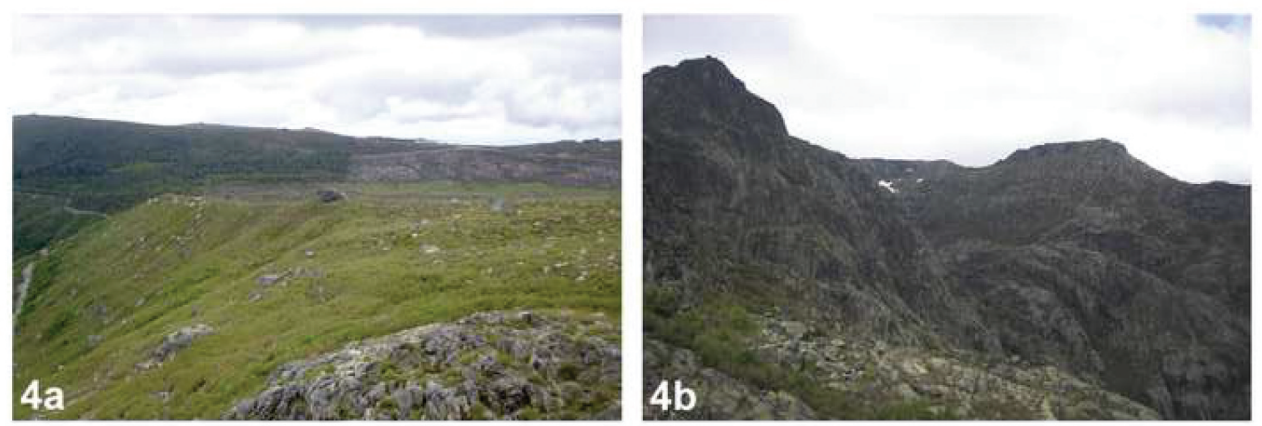

Figure 4. Glacial depositional and erosional landforms in the upper Zêzere glacial valley. (a): The Poio do Judeu lateral moraine. (b): Glacial cirque.

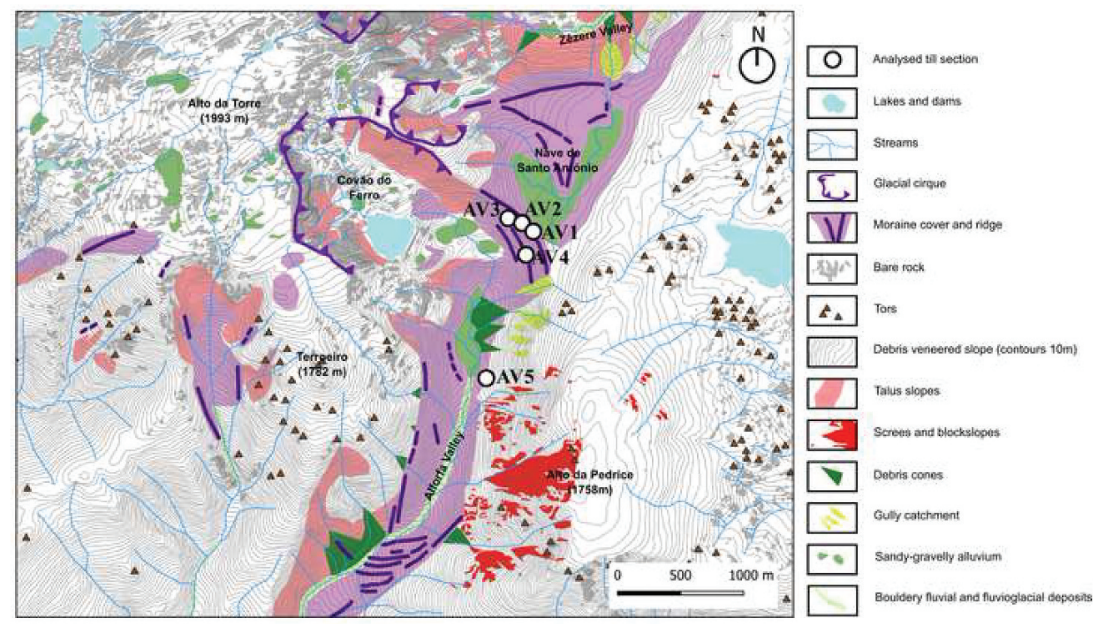

Figure 5. Geomorphic map of the Alforfa valley displaying sample sites and landforms and sediments (according to Vieira, 2004). Moraines and exposures codes: AV1- Alforfa valley lateral moraine 1 exposure 1 ; AV2- Alforfa valley lateral moraine 1 exposure 2; AV3- Alforfa valley lateral moraine 1 exposure 3; AV4- Alforfa valley lateral moraine 2 exposure 1; AV5- Alforfa mid-valley diamiction exposure 1.

These exposures are approximately 2.4 (exposure 1), 2.6 (exposure 2 ), and $2.1 \mathrm{~m}$ (exposure 3 ) thick and are all composed of one single sedimentary unit (Figure 6(b-d)). In all exposures, this unit is composed of a massive, very poorly sorted (average standard deviations for exposures 1,2 , and 3 of $2.20 \phi, 2.19 \phi$, and $2.16 \phi$, respectively), light brown, clast-rich, coarse sandy diamicton displaying average graphic means of $0.86 \phi$ (ranging from 0.83 to $0.88 \phi$ ) for exposure $1,0.93 \phi$ (ranging from 0.88 to $0.97 \phi$ ) for exposure 2 , and $0.96 \phi$ (ranging from 0.95 to $0.97 \phi$ ) for exposure 3 (Table 2). Clasts are composed of sub-angular to angular granite in all of the exposure's samples.

Data from these diamictons, in all exposures, indicates a weak to moderate fabric strength ( $\mathrm{S} 1$ averages for exposures 1,2 , and 3 of $0.57,0.59$, and 0.66 , respectively) (Table 

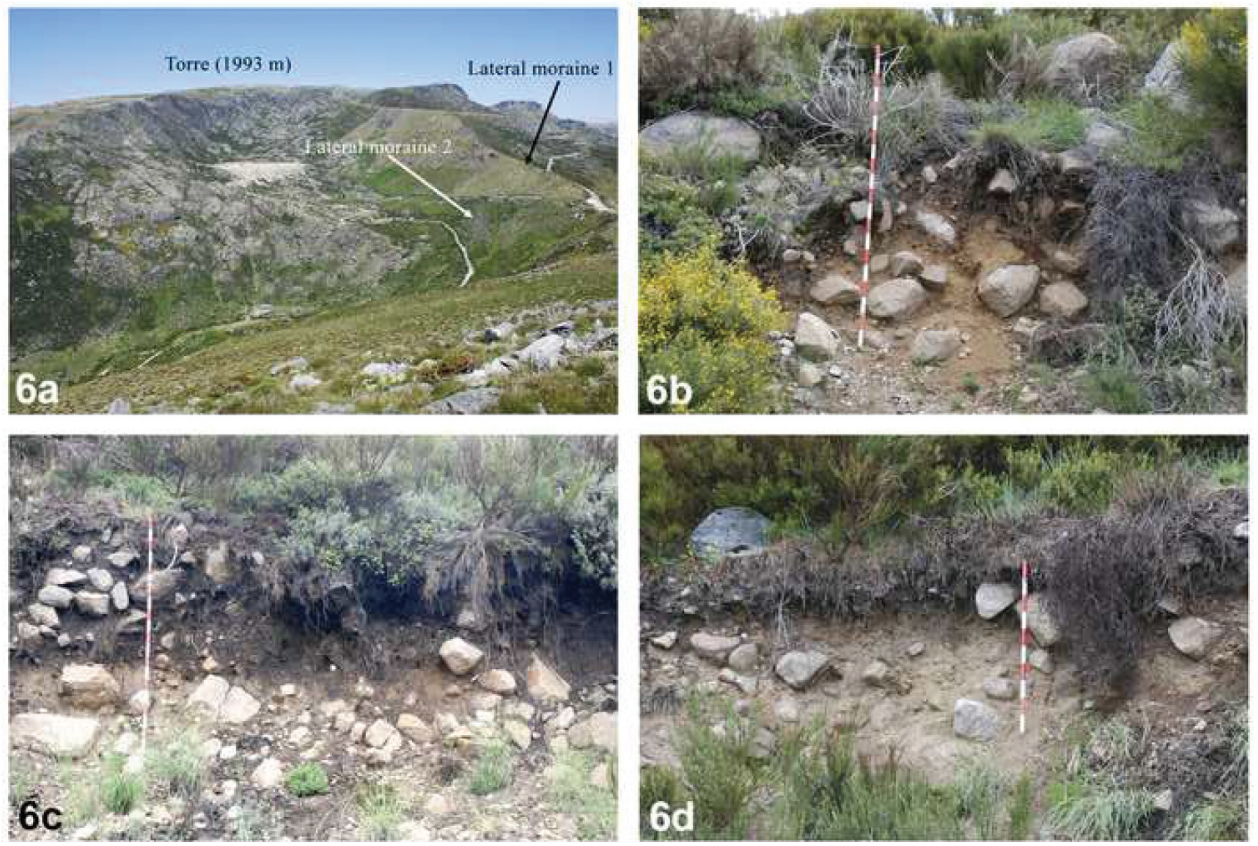

Figure 6. Glacial landforms and deposits on the Alforfa valley. (a): Alforfa valley lateral moraines 1 and 2. (b): Exposure 1 diamicton. (c): Exposure 2 diamicton. (d): Exposure 3 diamicton.
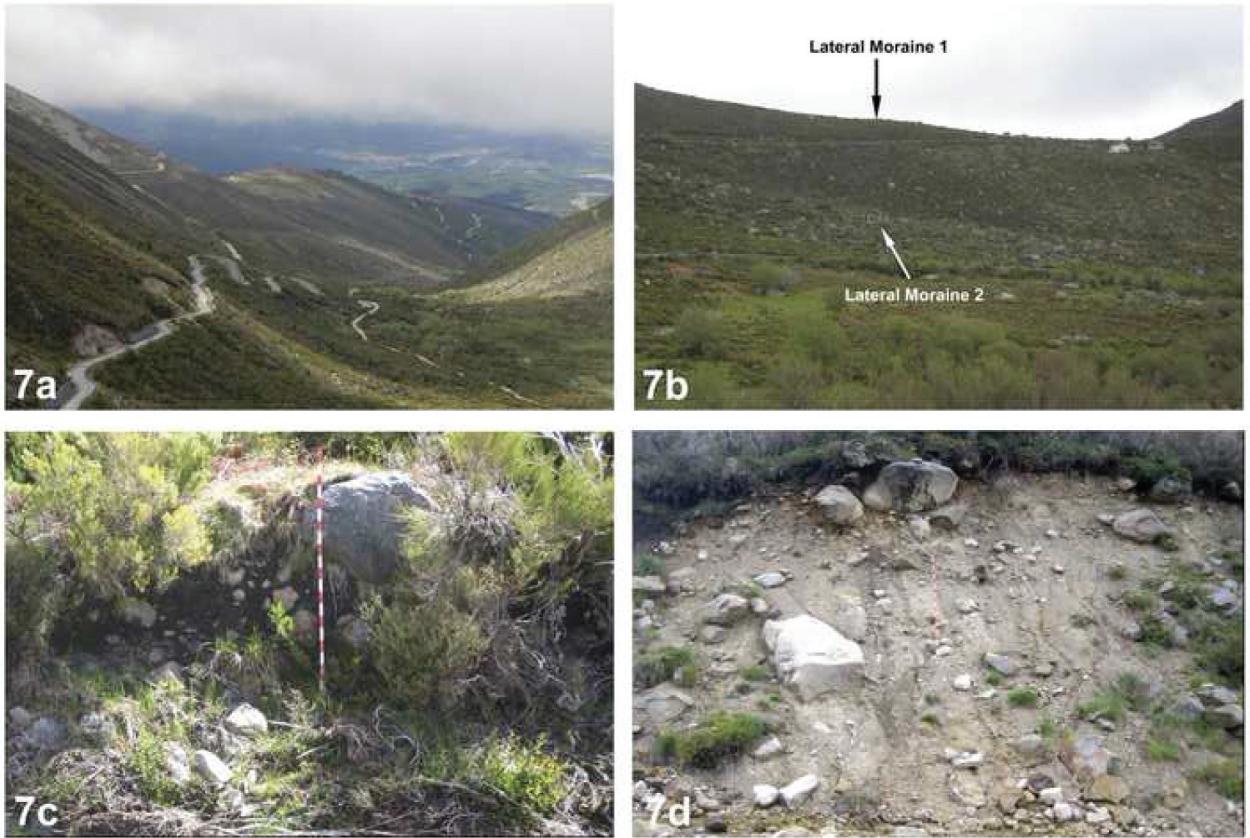

Figure 7. Glacial landforms and deposits on the Alforfa valley. (a): U-shaped profile of the Alforfa valley. (b): Alforfa valley lateral moraines 1 and 2. (c): Lateral moraine 2 exposure 1 diamicton. (d): Alforfa mid-valley diamicton exposure, probably affected by post glacial slope processes. 
1). Clasts are poorly oriented (V1 averages for exposures 1,2 , and 3 of $21^{\circ}, 22^{\circ}$, and $74^{\circ}$, respectively) (Figure 8) to the main paleo-ice flow NW-SE direction in these portions of the valley with a weak range in dip/plunge average values $\left(10^{\circ}\right.$ to $\left.19^{\circ}\right)$ for all exposures (Table 1$)$.

\section{Alforfa valley lateral moraine 2}

Lateral moraine 2 is a lateral-recessional moraine located in the upper and mid portions of the valley (Figures 5, 6(a) and 7(b)). One exposure present in the crest of this glacial landform was identified and sampled.

Exposure 1 is located at 1455 m.a.s.l. and $115 \mathrm{~m}$ above the valley floor. Ice thickness at this point must not have exceeded 115 to $120 \mathrm{~m}$. This exposure is approximately $2 \mathrm{~m}$ thick and is composed by one single sedimentary unit (Figure $7(\mathrm{c})$ ). This unit is composed of a massive, very poorly sorted (average standard deviation of 2.26 $\phi$ ), light brown, clast-rich, coarse sandy diamicton (average graphic mean of $0.90 \phi$ ranging from 0.83 to $0.97 \phi$ ) (Table 2). Clasts in the samples are composed of sub-angular to angular granite. Data from this deposit show a weak fabric strength (S1 average 0.57) (Table 1). Clasts are poorly oriented (V1 $13^{\circ}$ to $76^{\circ}$ ) (Figure 8 ) to the main paleo-ice flow NW-SE direction in this portion of the valley with a weak range in dip/plunge values $\left(6^{\circ}\right.$ to $\left.18^{\circ}\right)$ (Table 1$)$.

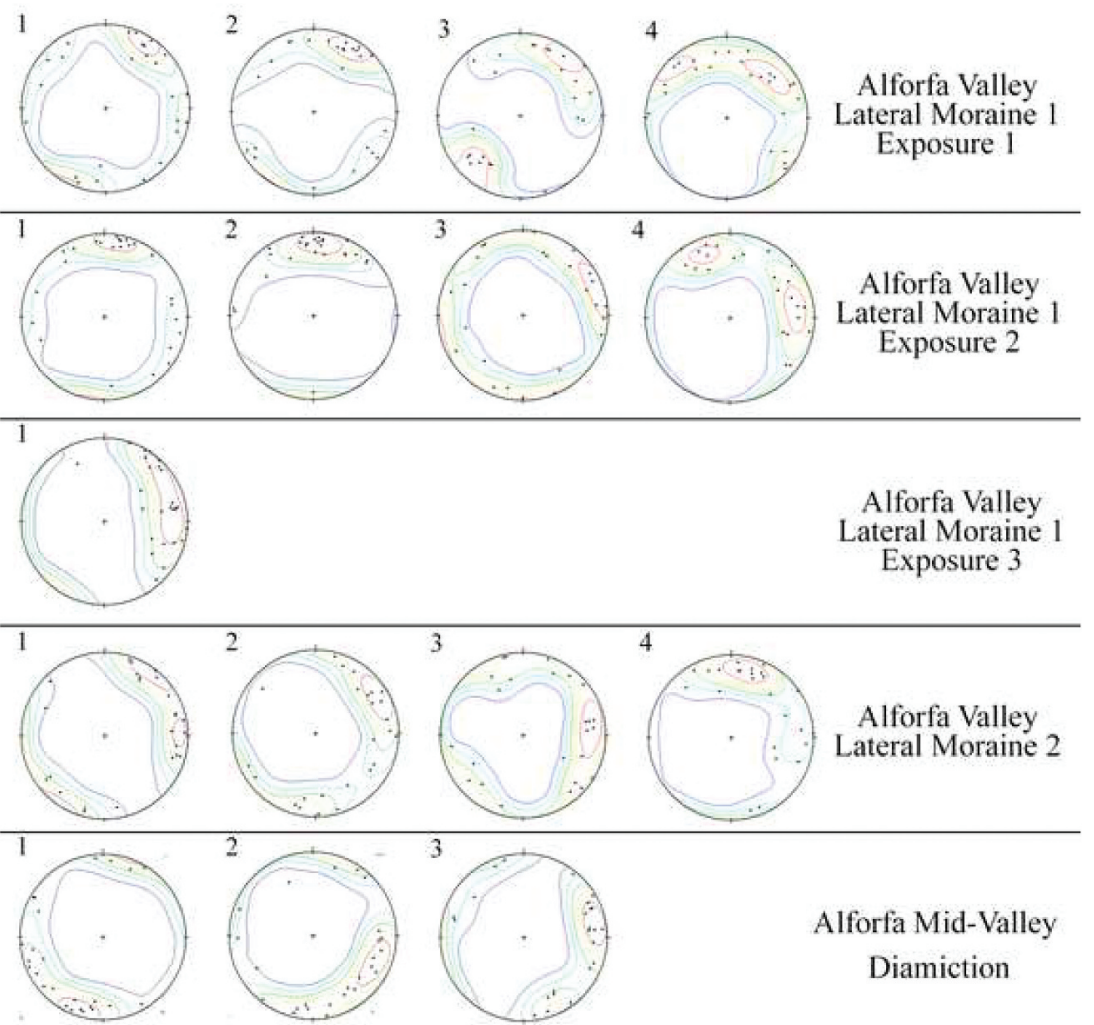

Figure 8. Alforfa valley fabric data plotted on equal-area nets. 


\section{Alforfa mid-valley diamicton}

A massive road-cut exposure present in the mid portion of Alforfa valley at 1398 m.a.s.l. and $70 \mathrm{~m}$ above the valley floor was identified and sampled (Figures 1 and 5).

The exposure is approximately $8 \mathrm{~m}$ thick and is also composed by one sedimentary unit (Figures 5 and $7(d)$ ). This unit is composed of a massive, very poorly sorted (average standard deviation of $2.17 \phi$ ), light brown, clast-rich, coarse sandy diamicton (average graphic mean of $0.79 \phi$ ranging from 0.72 to $0.85 \phi$ ) (Table 2 ). Clasts are mostly composed of granite and generally sub-angular to angular. The fabric displays poorly to moderately oriented clasts (V1 $103^{\circ}$ to $210^{\circ}$ ) (Figure 8) to the main paleo-ice flow N-S direction in this portion of the valley with a moderate range in dip/plunge values $\left(10^{\circ}\right.$ to $\left.16^{\circ}\right)$ (Table 1$)$. S1 values ranging from 0.53 to 0.66 are representative of a weak to a moderate fabric strength (Table 1).

The fabric data seem to indicate that a landslide, a paraglacial process that has been reported as normal in many mountain slopes after glaciation (Ballantyne, 2002; Evans et al., 2006; Santos-González et al., 2018), could have affected the original till deposit, modifying its directional properties. Thus, for the till deposit in this exposure, no precise information can be given by fabric analysis. The interpretation will be analyzed in detail in the discussion chapter.

\section{Zêzere valley}

The Zêzere valley is the longest glacial valley in these mountains and home to an array of glacial deposits and landforms (Figures 3, 4(a), and 4(b)). Three exposures present in a lateral moraine, a recessional moraine, and a road cut were identified and sampled in the upper, middle, and lower portions of this valley (Figures 1 and 9).

\section{Zêzere valley lateral moraine (also known as Poio do Judeu Moraine)}

The Poio do Judeu Moraine is a massive lateral moraine located in the upper portion of the valley (Figure 4(a)). It is the largest glacial depositional feature in the Zêzere valley. One exposure present in this feature was identified and sampled (Figures 1 and 9).

Exposure 1 is located at 1625 m.a.s.l. and $223 \mathrm{~m}$ above the valley floor (Figure 9). Ice thickness at this point (based on till observations in this area) must not have exceeded 220 to $230 \mathrm{~m}$. This exposure is approximately $2.5 \mathrm{~m}$ thick and is composed by one single sedimentary unit (Figure 10(a)). This unit is composed of a massive, very poorly sorted (average standard deviation of 2.19ф), light brown, clast-rich, coarse sandy diamicton (average graphic mean of $0.80 \phi$ ranging from 0.70 to $0.90 \phi$ ) (Table 2). Clasts in the samples are composed of sub-angular to angular granite. Data from this deposit displays a weak fabric strength (S1 average 0.57 ) (Table 1 ). Clasts are poorly oriented (V1 $220^{\circ}$ to $318^{\circ}$ ) (Figure 11) to the main paleo-ice flow WSW-ENE direction in this portion of the valley with a moderate to weak range in dip/plunge values $\left(2^{\circ}\right.$ to $\left.24^{\circ}\right)$ (Table 1$)$.

\section{Zêzere valley recessional moraine 3 (Lagoa Seca Complex)}

This recessional moraine is located on the mid-right section of the Zêzere valley at $1410 \mathrm{~m}$. a.s.l. (Figures 1 and 9). It is part of a morainal complex (known as the Lagoa Seca Complex) and is composed of a terminal moraine and three recessional moraines with a dry intermorainal lake located between the second and third recessional moraines (Figure 10(b)). Ice from the Zêzere valley glacier in this section of the valley exceeded $300 \mathrm{~m}$ in thickness and 


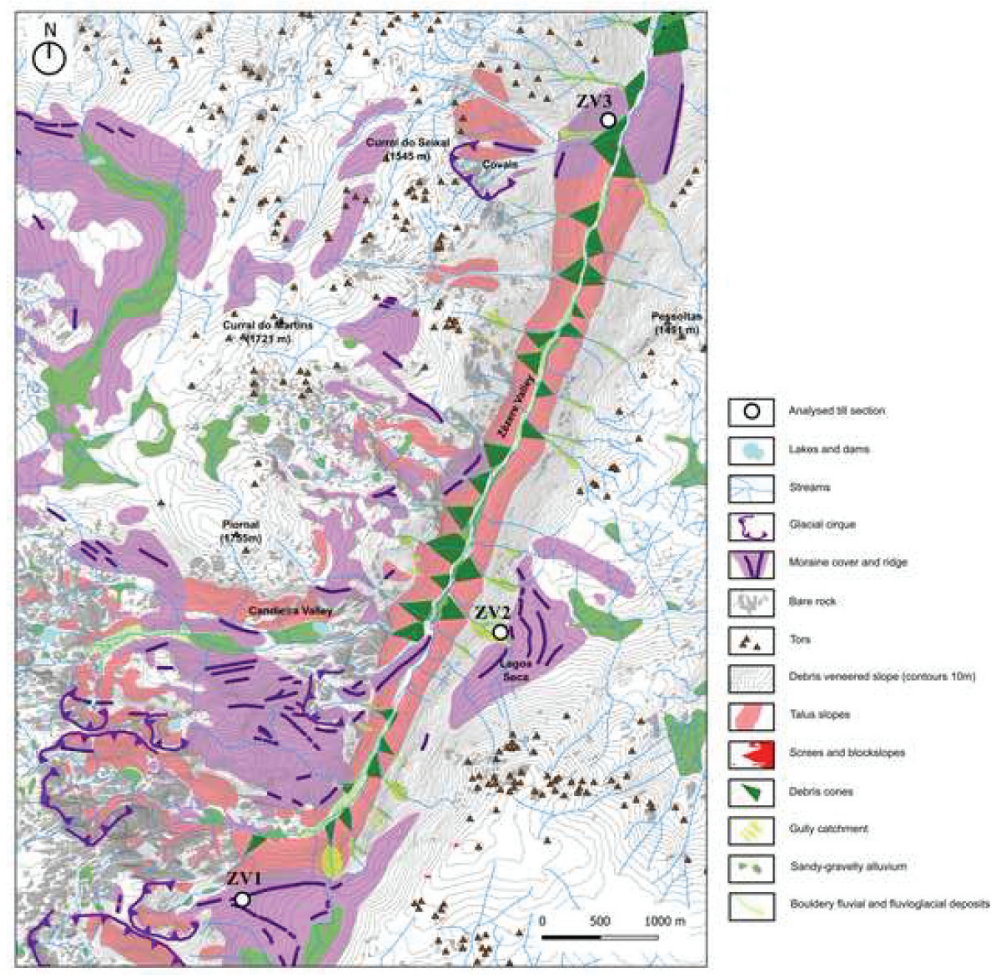

Figure 9. Geomorphic map of the Zêzere valley displaying sample sites and landforms and sediments (according to Vieira, 2004). Moraines and exposures codes: ZV1- Zêzere valley lateral moraine exposure $1 ;$ ZV2- Zêzere valley recessional moraine 3 exposure $1 ; Z V 3$ - Zêzere lower valley till exposure 1.

overflowed into the upper Beijames Valley generating a small ice tongue responsible for the genesis of this morainal complex (Vieira, 2004). One exposure present on the proximal side of this glacial landform was identified and sampled (see Figure 9 for location).

Exposure 1 is located at 1410 m.a.s.l. and $298 \mathrm{~m}$ above the valley floor (Figure 9). It is approximately $3.5 \mathrm{~m}$ thick and composed by two sedimentary units described by Vieira (2004), as a lower subglacial traction till and an upper flow till unit (Figure 10(c)). Due to logistical constraints to dig the lower unit, our analysis was restricted to the upper unit. This unit is composed of a very poorly sorted (average standard deviation of $2.16 \phi$ ), light brown, clast-rich, coarse to medium sandy diamicton (average graphic mean of $0.79 \phi$ ranging from 0.55 to $1.02 \phi$ ) (Table 2) exhibiting crude layering and soft-sediment deformation structures (Figure 10(c)). Clasts are composed of granite and are subangular to angular. The fabric essentially displays poorly oriented clasts with a few pockets of moderately oriented clasts $\left(\mathrm{V} 181^{\circ}\right.$ to $\left.135^{\circ}\right)$ (Figure 11 ) to the main paleoice flow SSW-NNE direction in this portion of the valley with a moderate range in dip/ plunge values $\left(12^{\circ}\right.$ to $\left.19^{\circ}\right)$ (Table 1$)$. S1 values ranging from 0.60 to 0.66 are representative of a moderate fabric strength (Table 1). 

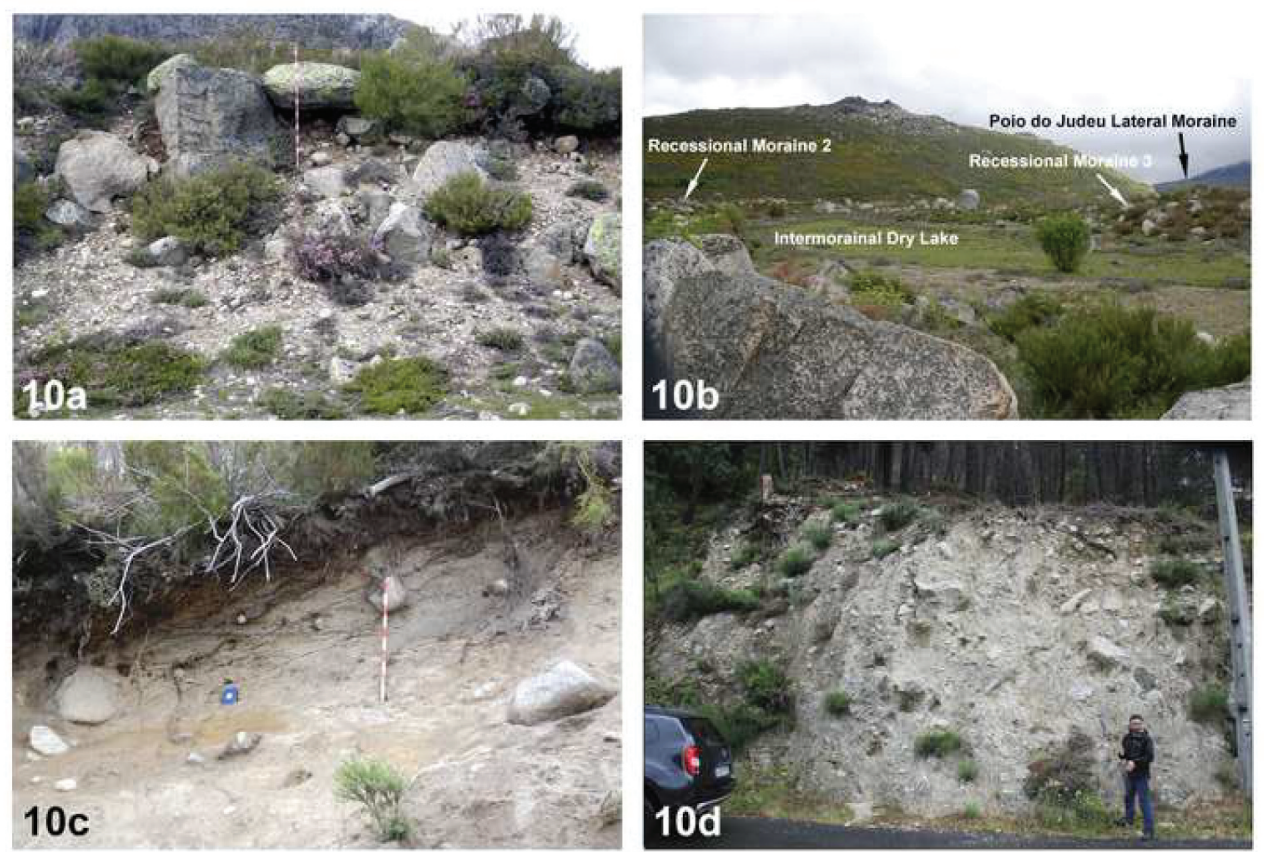

Figure 10. Glacial landforms and deposits on the Zêzere valley. (a): Poio do Judeu lateral moraine diamicton. (b): Intermorainal dry lake between recessional moraines 2 and 3 in the Lagoa Seca Complex. The Poio do Judeu lateral moraine is also visible. (c): Recessional moraine 3 diamicton exhibiting crude layering and soft-sediment deformation structures. (d): Zêzere lower valley diamicton.

\section{Zêzere lower valley till}

A massive road-cut exposure present in the lower portion of the Zêzere valley at 805 m.a. s.l. and $80 \mathrm{~m}$ above the valley floor was identified and sampled (see Figure 9).

The exposure is approximately $5 \mathrm{~m}$ thick and is composed of one single sedimentary unit (Figure 10(d)). This unit is composed of a massive, very poorly sorted (average standard deviation of $2.24 \phi$ ), light brown, clast-rich, coarse sandy diamicton (average graphic mean of $0.79 \phi$ ranging from 0.75 to $0.83 \phi$ ) (Table 2). Clasts in the samples are composed of sub-angular to angular granite. Data from this deposit show moderate to weak fabric strength (S1 average 0.63 ) (Table 1). Clasts are essentially poorly oriented (V1 $120^{\circ}$ to $220^{\circ}$ ) (Figure 11 ) to the main paleo-ice flow S-N direction in this portion of the valley with a very weak range in dip/plunge values (average $6^{\circ}$ ) (Table 1 ).

\section{Covão Grande valley}

Although less impressive than the Zêzere valley, the Covão Grande valley has noteworthy glacial landforms and deposits. Two exposures present in a lateral moraine were identified and sampled in the mid portion of this valley (Figures 1 and 12). 


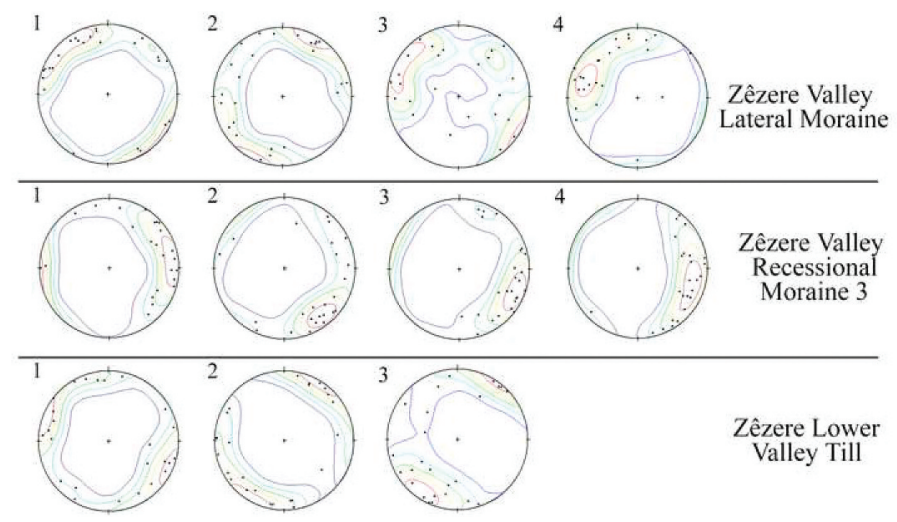

Figure 11. Zêzere valley fabric data plotted on equal-area nets.

\section{Covão Grande valley lateral moraine}

This lateral moraine is a lateral-terminal moraine located mainly in the mid and lower portions of the valley (Figure 13(a)). It is the largest glacial depositional feature (up to $1.7 \mathrm{~km}$ in length) in the Covão Grande valley and two exposures were sampled (Figure 12).

Exposure 1 is located at 1570 m.a.s.l. and $170 \mathrm{~m}$ above the valley floor (Figure 12). Ice thickness at this point must not have exceeded 170 to $180 \mathrm{~m}$. This exposure is approximately $1.2 \mathrm{~m}$ thick and is composed of one single sedimentary unit (Figure 13(b)). This unit is composed of a massive, very poorly sorted (average standard deviation of $2.30 \phi$ ), light brown, clast-rich, coarse sandy diamicton (average graphic mean of $0.88 \phi$ ranging from 0.87 to $0.88 \phi$ ) (Table 2). Clasts in the samples are composed of sub-angular to angular granite. Data from this deposit indicate a moderate fabric strength (S1 average 0.59 ) (Table 1). Clasts are moderately to well oriented (V1 average of $279^{\circ}$ ) (Figure 14) to

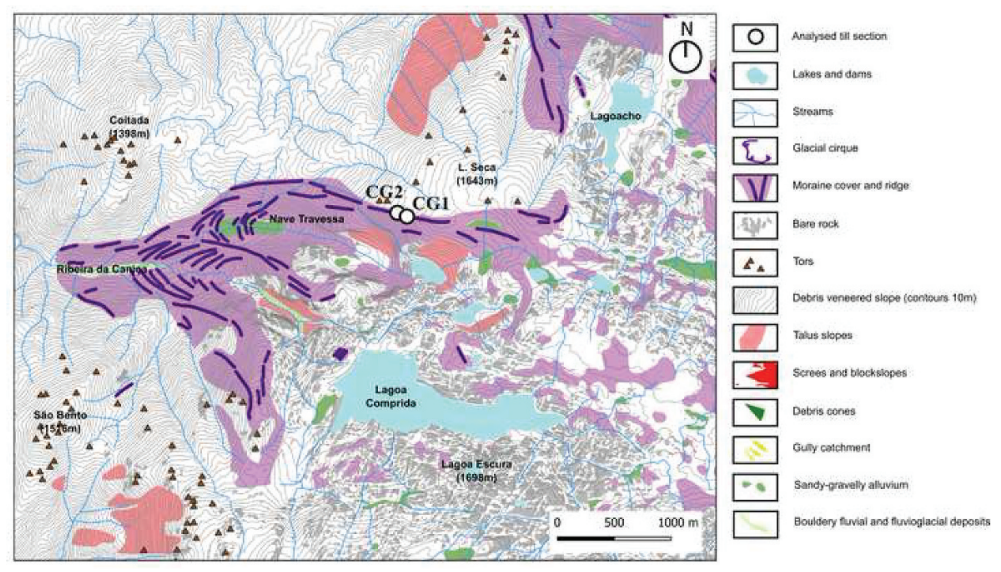

Figure 12. Geomorphic map of the Covão Grande valley displaying sample sites and landforms and sediments (according to Vieira, 2004). Moraines and exposures codes: CG1- Covão Grande valley lateral moraine exposure 1; CG2- Covão Grande valley lateral moraine exposure 2. 

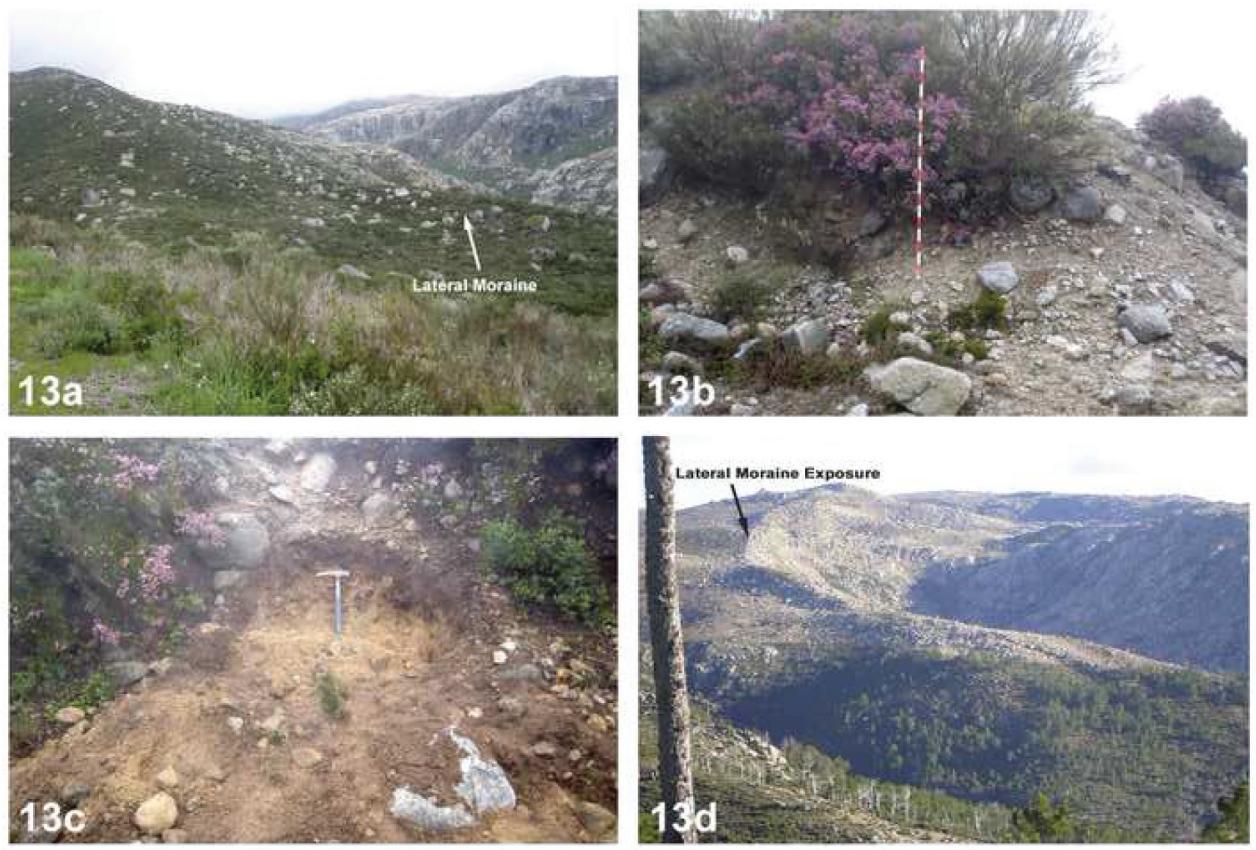

Figure 13. Glacial landforms and deposits on the Covão Grande and Covão do Urso valleys. (a): Covão Grande valley lateral moraine. (b): Covão Grande valley lateral moraine exposure 1 diamicton. (c): Covão Grande valley lateral moraine exposure 2 diamicton. (d): Covão do Urso valley lateral moraine with arrow showing exposure location.

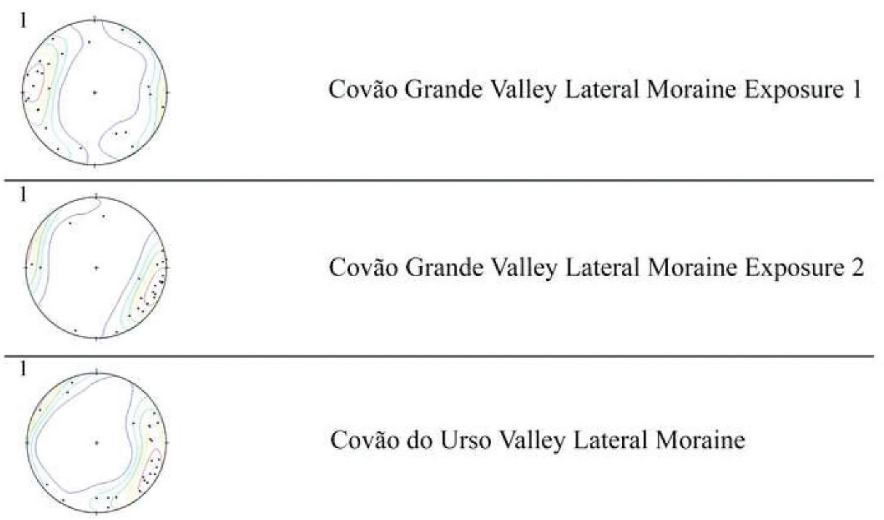

Figure 14. Covão Grande and Covão do Urso fabric data plotted on equal-area nets.

the main paleo-ice flow ESE-WNW direction in this portion of the valley with a moderate to weak range in dip/plunge values (average $10^{\circ}$ ) (Table 1).

Exposure 2 is located at 1568 m.a.s.l. and $168 \mathrm{~m}$ above the valley floor (Figure 12). It is approximately $1 \mathrm{~m}$ thick and displays one sedimentary unit (Figure 13(c)). This unit is composed of a very poorly sorted (average standard deviation of $2.15 \phi$ ), light brown, 
clast-rich, coarse sandy diamicton (average graphic mean of $0.70 \phi$ ) (Table 2). Clasts in the sample are composed of sub-angular granite and data from this deposit show moderate fabric strength (S1 average 0.75) (Table 1). Clasts are moderately to well oriented (V1 average of $111^{\circ}$ ) (Figure 14) to the main paleo-ice flow ESE-WNW direction in this portion of the valley with a moderate to weak range in dip/plunge values (average $8^{\circ}$ ) (Table 1).

\section{Covão do Urso valley}

The Covão do Urso valley also has many significant glacial landforms and deposits, however exposures are scarce. One exposure dug in a lateral moraine was sampled in the upper portion of this valley (Figures 1 and 15).

\section{Covão do Urso valley lateral moraine}

This lateral moraine is a massive lateral-terminal moraine. It is the largest glacial depositional feature (up to $4 \mathrm{~km}$ in length) (Figure 13(d)) in the entire Serra da Estrela Mountains (Vieira, 2004, 2008) and one exposure was sampled (see Figure 15).

Exposure 1 is located at 1440 m.a.s.l. and $221 \mathrm{~m}$ above the valley floor (Figures 13(d) and 15). Ice thickness at this point must not have exceeded $230 \mathrm{~m}$. This exposure is approximately $1.1 \mathrm{~m}$ thick and displays one sedimentary unit. This unit is composed of a very poorly sorted (average standard deviation of $2.18 \phi$ ), light brown, clast-rich, coarse sandy diamicton (average graphic mean of $0.64 \phi$ ranging from 0.55 to $0.73 \phi$ ) (Table 2 ). Clasts in the samples are composed of sub-angular to angular granite. Data from this deposit show a moderate fabric strength (S1 average 0.63) (Table 1). Clasts are moderately to well oriented (V1 average of $115^{\circ}$ ) (Figure 14) to the main paleo-ice flow SE-NW direction in this portion of the valley with a moderate to weak range in dip/plunge values (average $13^{\circ}$ ) $($ Table 1$)$.

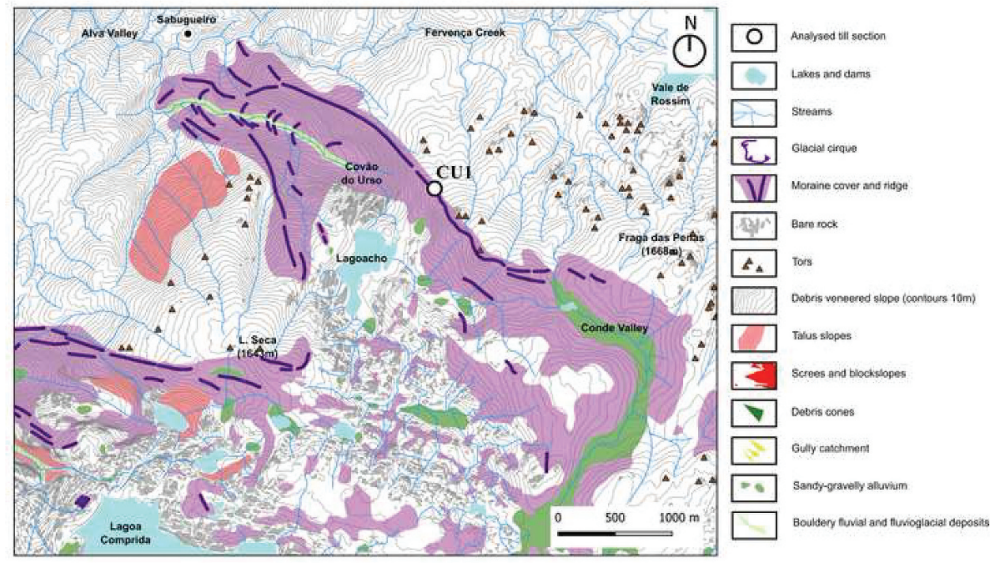

Figure 15. Geomorphic map of the Covão do Urso valley displaying sample sites and landforms and sediments (according to Vieira, 2004). Moraines and exposures codes: CU1- Covão do Urso valley lateral moraine exposure 1. 


\section{Interpretation and discussion}

Studies of moraine morphology and till sedimentology are important elements in reconstructing paleoglaciological dynamics. Fabric and grain size data, among other deposit characteristics, are the most relevant tool to infer glacial dynamics; nevertheless, other geomorphic data are typically required to complete paleoglaciological reconstructions.

In the Serra da Estrela Mountains, the preferred ice paleoflow direction in all glacial valleys studied seems to match the overall valleys' main orientation. In some cases, paleoflow directions are also supported by the orientations of lateral moraines (Zêzere lateral moraine and Alforfa lateral moraines 1 and 2) where main A-axis directions (V1) generally corresponded to the main orientation of these features.

Comparisons between fabrics show some differences between fabric shapes, especially in S1 values. The tertiary diagram introduced by Benn (1994) (Figure 16) and the biaxial diagram of Dowdeswell and Sharp (1986) (Figure 17) differentiate transitional fabrics obtained from flow tills from girdle to transitional fabrics from supraglacial melt-out tills (ablation tills) and remobilized till.

The moraine and till sedimentology present in the Serra da Estrela Mountains glacial valleys reveal the presence of at least two types of glacial till. In the Zêzere (lateral moraine and lower valley till) and Alforfa (lateral moraines 1 and 2) valleys, the clastrich, coarse sandy diamictons are interpreted to be supraglacial melt-out tills. Samples in these valleys present girdle to transitional fabrics (Figures 16 and 17) lacking a clear preferred main orientation with S1 eigenvalues (ranging from 0.47 to 0.77 ) (Table 1) expressing a weak to moderate fabric strength. In supraglacial melt-out tills pebble a-axis fabrics often have moderate to strong preferred orientations parallel to the ice flow direction (reflecting the original englacial fabrics) but ice fusion, meltwater dynamics, mass movements and sediments readjustments or, even post-depositional processes are all common in active or stagnant supraglacial environments and may overprint or change the original fabric (Evans, 2018; Ham \& Mickelson, 1994; Lawson, 1979). This seems to be the case when examining these diamictons. They all present a significant range in A-axis directions (V1) and S1 eigenvalues (Table 1), which supports the very heterogeneous nature of supraglacial melt-out till fabrics (Larson et al., 2016).

Results from the grain size analysis of these diamictons samples present unimodal to bimodal distributions and reveal they are composed of very poorly sorted, clast-rich, coarse sand with sub-angular to angular clasts. These characteristics are common in supraglacial melt-out tills where sediment is coarser and contains more angular clasts due to weathered debris falling on the ice from nearby active mountain slopes and the lack of crushing or striation common under and within moving ice (Haldorsen, 1981; Santos et al., 2017). Weathered sediments are angular and usually have similar sizes contributing to unimodal distributions (Benn \& Evans, 1996; Buller \& Mc Manus, 1973; Santos et al., 2015).

The clast-rich coarse to medium sandy diamicton exhibiting crude layering and softsediment deformation structures present in the Zêzere valley recessional moraine 3 is interpreted to be a flow till as proposed by Vieira (2004) using micromorphologic analysis. All samples from this diamicton present transitional fabrics (Figures 16 and 17) with poorly oriented clasts mixed with some pockets of moderately oriented clasts to 
Alforfa Lat. Moraine 1, Exp 1

O Alforfa Lat. Moraine 1, Exp 2

Alforfa Lat. Moraine 1, Exp 3

Alforfa Lat. Moraine 2

ㅁ Alforfa Mid-valley

\section{Isotropic}

$\triangle$ Zêzere Rec Moraine

$\Delta$ Zêzere Rec. Moraine

A Zêzere Lower Valley

- Covão Grande Exp 1

$\diamond$ Covão Grande Exp 2

$\star$ Covão do Urso

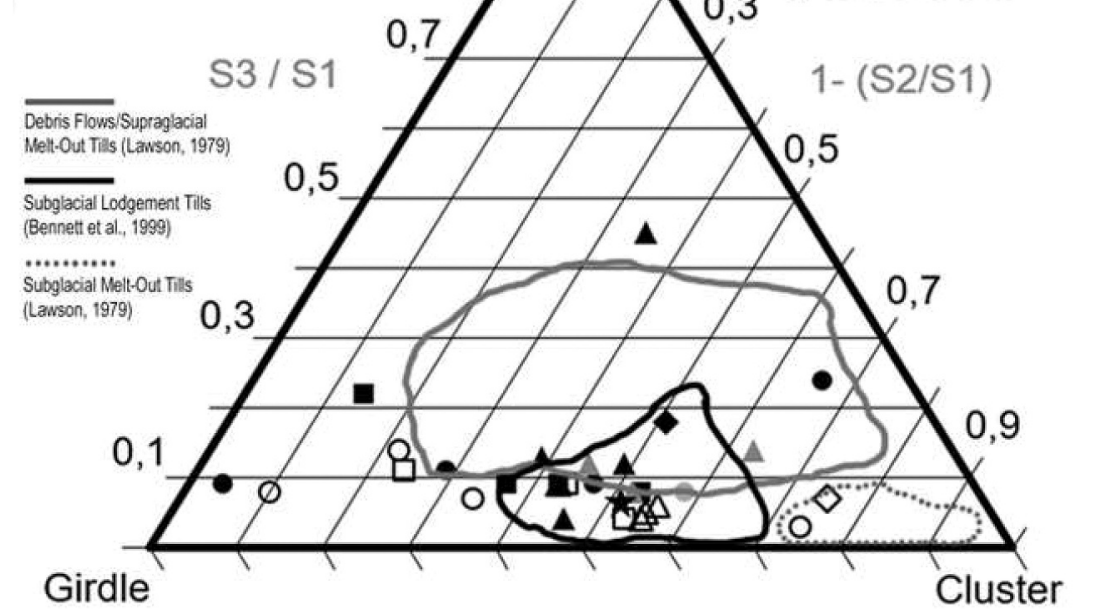

Figure 16. Eigenvalues plotted on the equilateral or general shape triangle introduced by.Benn (1994). Results are compared with data from Lawson (1979) and Bennett et al. (1999).

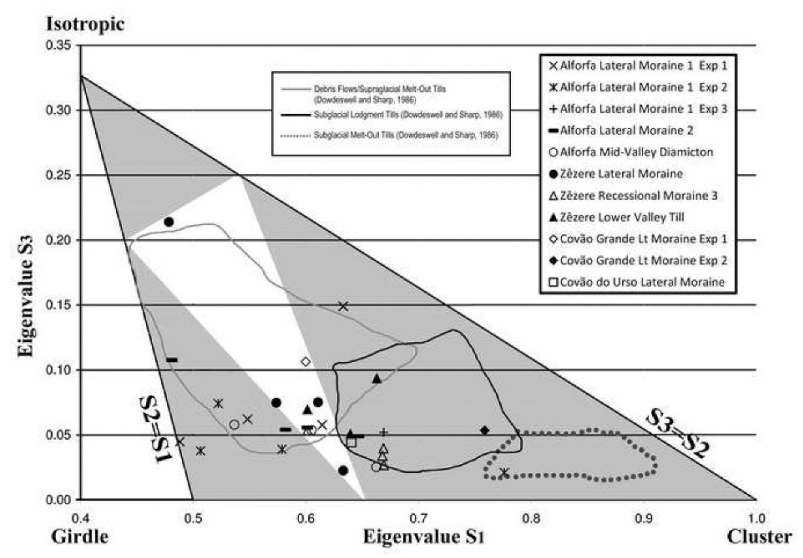

Figure 17. Plots of eigenvalues S1 and S3 in the biaxial diagram of .Dowdeswell and Sharp (1986). Results are compared with data from Dowdeswell and Sharp (1986).

the main paleo-ice flow direction (Figure 11) and S1 eigenvalues (ranging from 0.60 to 0.66) (Table 1) expressing a moderate fabric strength. Flow till is formed by the resedimentation, via mass movement, of sediments released by melt out from debris-rich glacier ice. This process usually leads to the genesis of crude layering and soft-sediment deformation structures (Bennett et al., 1999). According to Lawson (1982), the fabric strength and character of flow tills is largely a function of the fluidity of the depositional 
flow. Strong clustered fabrics may develop in fast, thin flows, whereas slow moving creeptype flows may develop girdle weak fabrics. Within and between flow packages rapid spatial variation in fabric is typical of reworking (Rose, 1974).

The grain size analysis results of the diamicton samples present unimodal to bimodal distributions and reveal they are composed mainly of very poorly sorted, clast-rich, coarse to medium sand. These characteristics are common in flow till where sediment is usually less coarse than in supraglacial melt-out till due to some degree of sorting during multiple episodes of re-sedimentation and contributions of fine-grained sediment from melting englacial debris bands (Boulton, 1968; Lawson, 1982). According to Bennett and Glasser (2009), some individual flow packages may in fact be sorted, however this characteristic was not observed in this diamiction.

The clast-rich, coarse sandy diamictons present in the mid portion of the Alforfa valley and in the lateral moraines of the Covão Grande and Covão do Urso valleys are interpreted to be a supraglacial melt-out tills remobilized and altered by post glacial mass-wasting activity. Their samples present girdle to transitional fabrics (Figures 16 and 17) with S1 eigenvalues (ranging from 0.53 to 0.75 ) (Table 1) expressing a weak to moderate fabric strength. The girdle fabrics support the genesis of the supraglacial meltout tills and the transitional fabrics presenting in many cases orientations both perpendicular and parallel to the valley's main orientation to their post glacial re-mobilization by mass-wasting activity. Poorly sorted coarse sand with unimodal to bimodal grain size distributions and sub-angular to angular clasts in these diamictions also support their supraglacial melt-out till genesis followed by post glacial mass-wasting re-mobilization with minor fluvial reworking.

Till macrofabric analysis data from other glaciated mountain systems in the Iberian Peninsula have also yielded similar results (Table 3). In the Cantabrian Mountains of northern Spain and in the Peneda and Gêres Mountains of northwest Portugal, SantosGonzález et al. (2013a), Santos et al. $(2015,2017)$ ) reported supraglacial melt-out tills displaying transitional-to-girdle fabrics with medium to high isotropic indexes and supraglacial melt-out tills remobilized by mass movements displaying transitional-togirdle fabrics. According to these authors the supraglacial melt-out tills represented glacial stabilization and recessional phases and the remobilized supraglacial melt-out tills post glacial (paraglacial) mass wasting processes, which are common in many mountain slopes after glaciation (Ballantyne, 2002; Evans et al., 2006; Santos-González et al., 2018).

With the newly obtained data, it is possible to reconstruct a hypothetical/tentative deglacial paleoprocess history for the study area. In stage one, likely during and near the end of the local LGM, periods of glacial stability followed by recession deposited the supraglacial melt-out tills present in the Zêzere lower valley exposure and in the lateralterminal and lateral-recessional moraines present in the Alforfa and Zêzere valleys. All these moraines are therefore interpreted to be dump moraines. The flow till present in the Zêzere valley recessional moraine 3 (Lagoa Seca Complex) was also deposited during a phase of stability followed by recession and re-sedimentation, via mass movement, of sediments released by melt out from debris-rich ice from the Zêzere glacier as it receded from the upper Beijames Valley. In stage two, after the local LGM, as ice quickly receded from these valleys, post glacial slope processes occurred as shown by the remobilized 
supraglacial melt-out tills present in the Alforfa mid valley exposure and in the lateral moraines of the Covão Grande and Covão do Urso valleys.

Currently, the glacial chronology of the Serra da Estrela Mountains based in absolute dating methods is still incomplete. Chronological data based on cosmogenic ${ }^{36} \mathrm{Cl}$ dating of moraine boulders and glacially polished outcrops from several locations in the mountains of the Iberian Central System (Serra da Estrela, Portugal and Sierra de Gredos and Sierra de Guadarrama, Spain) suggest ages of 31 and $26 \mathrm{ka} \mathrm{BP}$ for the local LGM with fast retreat occurring after 16-15 ka BP, when glaciers completely abandoned the valleys (Palacios et al., 2012, 2011; Vieira \& Palacios, 2010). In the Cantabrian Mountains of northern Spain, several datasets suggest a glacial maximum earlier than 30,000 to 60,0000 years BP (Frochoso et al., 2013; Jalut et al., 2010; Jiménez-Sánchez et al., 2013; Serrano et al., 2013). In the Sanabria Mountains of northwest Spain, Pérez-Alberti et al. (2011) and RodríguezRodríguez et al. (2011) present minimum ages of 21 to $33 \mathrm{ka} \mathrm{BP}$ for the local LGM. All these ages seem to point out some synchrony in the events related to the time of the LGM in the northern and central portions of the Iberian Peninsula.

\section{Conclusion}

Till macrofabric and grain size analysis in the Serra da Estrela Mountains were used to reconstruct glacial dynamics in this mountainous region. An icefield with several outlet glaciers developed depositing numerous glacial diamictons and moraines. Using the orientation dips of clasts and grain size analysis it was possible to discern:

- Supraglacial melt-out tills, representative of glacial stability followed by recession, normally presenting weaker fabric data and coarser, poorly sorted sediments.

- Flow till, mainly representative of glacial stability followed by recession, presenting moderate fabric data and coarser to fine, poorly sorted sediments.

- Glacial deposits affected by post glacial paraglacial activity such as landslides presenting weaker to moderate fabric data and coarser, poorly sorted sediments.

These glacial diamictons and moraines confirm the importance of the Quaternary glaciations in the Serra da Estrela Mountains. Some chronological data about the time of glaciation in these mountains based on absolute dating exists but an extra effort is

Table 3. Clast fabric strength (S1 eigenvalue) for tills from different field case studies, including data from the Serra da Estrela Mountains.

\begin{tabular}{|c|c|c|c|}
\hline Case study (reference) & Till type & $\begin{array}{l}\text { S1 eigenvalue } \\
\text { range }\end{array}$ & $\begin{array}{l}\text { S1 eigenvalue } \\
\text { mean }\end{array}$ \\
\hline \multirow[t]{2}{*}{$\begin{array}{l}\text { Santos-González et al., 2013a (Cantabrian } \\
\text { Mountains) }\end{array}$} & $\begin{array}{l}\text { Supraglacial melt-out } \\
\text { till }\end{array}$ & $0.54-0.67$ & 0.51 \\
\hline & Remobilized till & $0.51-0.76$ & 0.61 \\
\hline Santos et al., 2015(Serra da Peneda Mountains) & $\begin{array}{l}\text { Supraglacial melt-out } \\
\text { till }\end{array}$ & $0.44-0.74$ & 0.58 \\
\hline \multirow[t]{2}{*}{ Santos et al., 2017 (Serra do Gerês Mountains) } & $\begin{array}{l}\text { Supraglacial melt-out } \\
\text { till }\end{array}$ & $0.46-0.72$ & 0.57 \\
\hline & Remobilized till & $0.53-0.88$ & 0.71 \\
\hline \multirow[t]{2}{*}{ Serra da Estrela Mountains } & $\begin{array}{l}\text { Supragalcial melt-out } \\
\text { till }\end{array}$ & $0.47-0.77$ & 0.59 \\
\hline & Remobilized till & $0.53-0.75$ & 0.63 \\
\hline
\end{tabular}


needed in order to refine the glacial chronology for each individual glaciated valley. An important question that should be answered by future research is about whether or not there was glacial synchrony in all glaciated valleys.

Despite their modest elevation (1993 m.a.s.l.) and location in southwestern Europe, significant glaciation took place and an icefield with several glacial tongues developed. The moist climate of this mountain range (currently over $2500 \mathrm{~mm}$ of annual precipitation) probably influenced glacial development making it an interesting site for reconstructing paleoclimatic dynamics in southern Europe and glacial responses to climate change.

\section{Acknowledgments}

We thank the Association Geopark Estrela of Portugal for sharing information and for assisting with field logistics. We also thank the Department of Geology at San Jose State University and Ryan Portner, Director of the Sedimentology Lab, for supporting the grain size analysis work.

\section{Disclosure statement}

No potential conflict of interest was reported by the authors.

\section{ORCID}

Gonçalo Vieira (D) http://orcid.org/0000-0001-7611-3464

Javier Santos-González (D) http://orcid.org/0000-0002-5567-653X

Barbara Woronko (D) http://orcid.org/0000-0002-2763-5650

\section{References}

Andrade, E., Mora, C., Neves, M., \& Vieira, G. (1992). Desportos de Inverno na Serra da Estrela. Contribuição para o estudo da sua viabilidade. Finisterra, 27(53-54), 187-193.

Andrews, J. T. (1971). Techniques of till fabric analysis. British Geomorphological Research Group. Technical Bulletin No. 6.

Ballantyne, C. K. (2002). Paraglacial geomorphology. Quaternary Science Reviews, 21(18-19), 1935-2017. https://doi.org/10.1016/S0277-3791(02)00005-7

Benn, D. I. (1994). Fabric shape and the interpretation of sedimentary data. Journal of Sedimentary Research, 64(4a), 910-915.

Benn, D. I., \& Evans, D. J. A. (1996). The interpretation and classification of subglacially deformed materials. Quaternary Science Reviews, 15(1), 23-52. https://doi.org/10.1016/0277-3791(95) 00082-8

Benn, D. I., \& Evans, D. J. A. (1998). Glaciers and glaciation. Arnold.

Bennett, M. R., \& Glasser, N. F. (2009). Glacial geology: Ice sheets and landforms. In Oxford (pp. 385). Wiley-Blackwell.

Bennett, M. R., Waller, R. I., Glasser, N. F., Hambrey, M. J., \& Huddart, D. (1999). Glacigenic clast fabric: Genetic fingerprint or wishful thinking? Journal of Quaternary Science, 14(2), 125-135. https://doi.org/10.1002/(SICI)1099-1417(199903)14:2<125::AID-JQS426>3.0.CO;2-0

Boulton, G. (1968). Flow Tills and related deposits on some vestspitsbergen glaciers. Journal of Glaciology, 7(51), 391-412. https://doi.org/10.1017/S0022143000020608

Buller, A., \& Mc Manus, J. (1973). The quartile-deviation/median-diameter relationships of glacial deposits. Sedimentary Geology, 10(2), 135-146. https://doi.org/10.1016/0037-0738(73)90003-1

Cabral, F. A. (1884). Vestígios glaciários na Serra da Estrela. In Revista de Obras Públicas e Minas, Lisboa (pp. 435-459). 
Carlson, A. E., Jenson, J. W., \& Clark, U. (2004). Sedimentological observations from the Tiskilwa Till, Illinois, and Sky Pilot Till, Manitoba. Géographie Physique et Quaternaire, 58(2-3), 229-239. https://doi.org/10.7202/013140ar

Carr, S. J., \& Rose, J. (2003). Till fabric patterns and significance: Particle response to subglacial stress. Quaternary Science Reviews, 22(14), 1415-1426. https://doi.org/10.1016/S0277-3791(03) 00125-2

Daveau, S. (1971). La glaciation de la Serra da Estrela. Finisterra, 6(11), 5-40. https://doi.org/10. 18055/Finis2431

Daveau, S., Coelho, C., Costa, V. G., \& Carvalho, L. (1977). Répartition et Rythme des Précipitations au Portugal. Memórias do Centro de Estudos Geográficos, 3, 1-192.

Dowdeswell, J., \& Sharp, M. (1986). Characterization of pebbles fabric in modern terrestrial glacigenic sediments. Sedimentology, 33(5), 699-710. https://doi.org/10.1111/j.1365-3091. 1986.tb01970.x

Easterbrook, D. (1999). Surface process and landforms. Prentice Hall.

Evans, D. J. A. (2018). Till: A glacial process sedimentology. Wiley Blacwell Cryosphere Science Series.

Evans, D. J. A., Phillips, E. R., Hiemstra, J. F., \& Auton, C. A. (2006). Subglacial till: Formation, sedimentary characteristics and classification. Earth-Science Reviews, 78(1-2), 115-176. https:// doi.org/10.1016/j.earscirev.2006.04.001

Evans, D. J. A., Shulmeister, J., \& Hyatt, O. (2010). Sedimentology of latero-frontal moraines and fans on the west coast of South Island, New Zealand. Quaternary Science Reviews, 29(27-28), 3790-3811. https://doi.org/10.1016/j.quascirev.2010.08.019

Folk, R. (1955). Student operator error in determination of roundness, sphericity, and grain size. Journal of Sedimentary Petrology, 25, 297-301.

Folk, R. (1966). A review of grain-size parameters. Sedimentology, 6(2), 73-93. https://doi.org/10. 1111/j.1365-3091.1966.tb01572.x

Frochoso, M., González-Pellejero, R., \& Allende, F. (2013). Pleistocene glacial morphology and timing of last glacial cycle in Cantabrian Mountains (Northern Spain): New chronological data from the Asón Area. Central European Journal of Geosciences, 5(1), 12-27. https://doi.org/10. 2478/s13533-012-0117-8.

González-Gutiérrez, R. B., Santos-González, J., Gómez-Villar, A., \& Redondo-Vega, J. M. (2019). Surface macro-fabric analysis of relict rock glaciers in the Cantabrian Mountains (NW Spain). Permafrost and Periglacial Processes, 30(4), 348-363. https://doi.org/10.1002/ppp.2025

Haldorsen, S. (1981). Grain-size distribution of subglacial till and its relation to subglacial crushing and abrasion. Boreas, 10(1), 91-105. https://doi.org/10.111/j.1502-3885.1981.tb00472.x

Ham, N. R., \& Mickelson, D. M. (1994). Basal till fabric and deposition at Burroughs Glacier, Glacier Bay, Alaska. Geological Society of America Bulletin, 106(12), 1552-1559. https://doi.org/ 10.1130/0016-7606(1994)106<1552:BTFADA >2.3.CO;2

Hart, J. K. (1994). Till fabric associated with deformable beds. Earth Surface Processes and Landforms, 19(1), 15-32. https://doi.org/10.1002/esp.3290190103

Jalut, G., Turu I Michels, V., Dedoubat, J. J., Otto, T., Ezquerra, J., Fontugne, M., Belet, J. M., Bonnet, L., García de Celis, A., Redondo-Vega, J. M., Vidal-Romaní, J. R., \& Santos, L. (2010). Palaeoenvironmental studies in NW Iberia (Cantabrian range): Vegetation history and synthetic approach of the last deglaciation phases in the western Mediterranean. Palaeogeography, Palaeoclimatology, Palaeoecology, 297(2), 330-350. https://doi.org/10.1016/j.palaeo.2010.08.012

Jiménez-Sánchez, M., Rodríguez-Rodríguez, L., García-Ruiz, J. M., Domínguez-Cuesta, M. J., Farias, P., Valero-Garcés, B., Moreno, A., Rico, M., \& Valcárcel, M. (2013). A review of glacial geomorphology and chronology in northern Spain: Timing and regional variability during the last glacial cycle. Geomorphology, 196, 50-64. https://doi.org/10.1016/j.geomorph.2012.06.009

Johnson, M. D. (1990). Fabric and origin of diamictons in end moraines, Animas River Valley, Colorado, U.S.A. Arctic and Alpine Research, 22(1), 14-25. https://doi.org/10.2307/1551717

Kamb, N. B. (1959). Ice petrofabric observations from Blue Glacier, Washington, in relation to theory and experiment. Journal of Geophysical Research, 64(11), 1891-1909. https://doi.org/10. 1029/JZ064i011p01891 
Karlstrom, E. T., \& Barendregt, R. W. (2001). Fabric, paleomagnetism, and interpretation of pre-Illinoian diamictons and paleosols on Cloudy Ridge and Milk River Ridge, Alberta and Montana. Géographie Physique et Quaternaire, 55(2), 141-157. https://doi.org/10.7202/ 008299ar

Kjær, K. H., \& Krüger, J. (1998). Does clast size influence fabric strength? Journal of Sedimentary Research, 68(5), 746-749. https://doi.org/10.2110/jsr.68.746

Krumbein, W. (1934). Size frequency distribution of sediments. Journal of Sedimentary Petrology, 4(2), 65-77. https://doi.org/10.1306/D4268EB9-2B26-11D7-8648000102C1865D

Lachniet, M. S., Larson, G. J., Strasser, J. C., Lawson, D. E., Evenson, E. B., \& Alley, R. B. (1999). Microstructures of glacigenic sediment-flow deposits, Matanuska Glacier, Alaska. Geological Society of America Special Paper, 337, 45-57.

Larsen, N. K., Piotrowski, J. A., \& Kronborg, C. (2004). A multiproxy study of a basal till: A time-transgressive accretion and deformation hypothesis. Journal of Quaternary Science, 19(1), 9-21. https://doi.org/10.1002/jqs.817

Larson, G., Menzies, J., Lawson, D. E., Evenso, E. B., \& Hopkins, N. R. (2016). Macro- and microsedimentology of a modern melt-out till-Matanuska Glacier, Alaska, USA. Boreas, 45(2), 235-251. https://doi.org/10.1111/bor.12149

Lautensach, H. (1929). Eiszeitstudien in der Serra da Estrela, Portugal. Zeitschrift für Gletscherkunde, 18, 324-369.

Lautensach, H. (1932). Estudo dos glaciares da Serra da Estrela. Memórias e Notícias, Coimbra, 6, 1-60.

Lawson, D. E. (1979). Sedimentological analysis of the western terminus region of the Matanuska Glacier (p. 79). U.S. Army Cold Regions Research and Engineering Laboratory Report.

Lawson, D. E. (1981). Distinguishing characteristics of diamictons at the margin of the Matanuska Glacier, Alaska. Annals of Glaciology, 2(1), 78-84.

Lawson, D. E. (1982). Mobilization, movement and deposition of active subaerial sediment flows, Matanuska Glacier, Alaska. Journal of Geology, 90(3), 279-300. https://doi.org/10.1086/628680

Li, D., Yi, C., Ma, B., Wang, P., Ma, C., \& Cheng, G. (2006). Fabric analysis of till clasts in the upper Urumqi River, Tian Shan, China. Quaternary International, 154-155, 19-25. https://doi.org/10. 1016/j.quaint.2006.02.016

Mark, D. (1973). Analysis of axial orientation data, including till fabrics. Geological Society of America Bulletin, 84(4), 1369-1374. https://doi.org/10.1130/0016-7606(1973)84<1369: AOAODI $>2.0 . \mathrm{CO} ; 2$

Migón, P., \& Vieira, G. (2014). Granite geomorphology and its geological controls, Serra da Estrela, Portugal. Geomorphology, 226, 1-14. https://doi.org/10.1016/j.geomorph.2014.07.027

Millar, S. W. (2006). Processes dominating macro-fabric generation in periglacial colluvium. Catena, 67(1), 79-87. https://doi.org/10.1016/j.catena.2006.03.003

Mora, C. (2010). A synthetic map of the climatopes of the Serra da Estrela (Portugal). Journal of Maps, 2010(1), 591-608. https://doi.org/10.4113/jom.2010.1112

Nichols, G. (1999). Sedimentology and stratigraphy. Blackwell Science.

Palacios, D., Andrés, N., Vieira, G., Marcos, J., \& Vázquez-Selem, L. (2012). Last glacial maximum and deglaciation of the Iberian central system. Geophysical Research abstracts, 14, 2012-3738.

Palacios, D., Marcos, J., \& Vázquez-Selem, L. (2011). Last glacial maximum and deglaciation of Sierra de Gredos, central Iberian Peninsula. Quaternary International, 233(1), 16-26. https:// doi.org/10.1016/j.quaint.2010.04.029

Pérez-Alberti, A., Valcárcel-Díaz, M., Martini, I. P., Pascucci, V., \& Andreucci, S. (2011). Upper Pleistocene glacial valley-junction sediments at Pias, Trevinca Mountains, NW Spain. In I. P. Martini, H. M. French, \& A. Pérez-Alberti (Eds.), Ice-marginal and periglacial processes and sediments (pp. 93-110). Geological Society Special Publications, 354.

Redondo-Vega, J. M., González-Gutiérrez, R. B., Santos-González, J., \& Gómez-Villar, A. (2006). Sedimentación glaciolacustre en la Montaña Cantábrica Leonesa [Glaciolacustrine deposits in the Leonese area of Cantabrian Mountains]. In A. Pérez-Alberti \& J. López-Bedoya (Eds.), 
Geomorfología y territorio [Geomorphology and territory] (pp. 83-100). Universidade de Santiago de Compostela.

Ribeiro, A. (1988). A Tectónica Alpina em Portugal. Geonovas, 10, 8-11.

Rodríguez-Rodríguez, L., Jiménez-Sánchez, M., Domínguez-Cuesta, M. J., Rico, M. T., \& ValeroGarcés, B. (2011). Last deglaciation in northwestern Spain: New chronological and geomorphologic evidence from the Sanabria region. Geomorphology, 135(1-2), 48-65. https://doi.org/ 10.1016/j.geomorph.2011.07.025

Rose, J. (1974). Small-scale spatial variability of some sedimentary properties of lodgement till and slumped till. Proceedings of the Geologists' Association, 85(2), 239-258. https://doi.org/10.1016/ S0016-7878(74)80026-X

Santos, J. A., \& Cunha, L. J. (2012). Till fabric analysis and origin of Portage glacier little ice age moraines, south-central Alaska. Polar Geography, 35(1), 65-81. https://doi.org/10.1080/ 1088937X.2012.663413

Santos, J. A., Cunha, L. J., Vieira, A. A., \& Bento-Gonçalves, A. J. (2013, February). Genesis of the Alto Vez Glacial Valley Pleistocene Moraines, Peneda Mountains, Northwest Portugal. Proceedings of the 6th Bi-annual conference of the association of Portuguese geomorphologists (pp. 57-62). Coimbra.

Santos, J. A., Santos-González, J., \& Redondo-Vega, J. M. (2015). Till fabric analysis and origin of late quaternary moraines in the Serra da Peneda Mountains, NW Portugal. Physical Geography, 36(1), 1-18. https://doi.org/10.1080/02723646.2014.961218

Santos, J. A., Santos-González, J., Redondo-Vega, J. M., \& Irwin, J. R. (2017). Glacial deposits in the Serra do Gerês Mountains (NW Iberian Peninsula): Till macrofabric analysis. Physical Geography, 38(3), 263-285. https://doi.org/10.1080/02723646.2016.1276879

Santos-González, J. (2012). Glaciarismo y periglaciarismo en el Alto Sil, provincia de León (Cordillera Cantábrica) [Glacial and periglacial geomorphology in the alto Sil area (Cantabrian Mountains)]. Universidad de León. CD-ROM.

Santos-González, J., González-Gutiérrez, R. B., Santos, J. A., Gómez-Villar, A., Peña-Pérez, S. A., \& Redondo-Vega, J. M. (2018). Topographic, lithologic and glaciation style influences on paraglacial processes in the upper Sil and Luna catchments, Cantabrian Mountains, NW Spain. Geomorphology, 319, 133-146. https://doi.org/10.1016/j.geomorph.2018.07.019

Santos-González, J., Redondo-Vega, J. M., González Gutiérrez, R. B., \& Gómez Villar, A. (2015). Nuevos datos sobre el origen del Lago de la Baña (Sierra de la Cabrera, NO de España) a partir del análisis geomorfológico y sedimentológico. Boletín de la AGE, 67, 61-81. doi:10.21138/ bage. 18.17

Santos-González, J., Redondo-Vega, J. M., González-Gutiérrez, R. B., \& Gómez-Villar, A. (2013b). Applying the AABR method to reconstruct equilibrium-line altitudes from the last glacial maximum in the Cantabrian Mountains (SW Europe). Palaeogeography, Palaeoclimatology, Palaeoecology, 387, 185-199. https://doi.org/10.1016/j.palaeo.2013.07.025

Santos-González, J., Santos, J. A., González-Gutiérrez, R. B., Redondo-Vega, J. M., \& GómezVillar, A. (2013a). Till fabric and grain-size analysis of glacial sequences in the Upper Sil River Basin, Cantabrian Mountains, NW Spain. Physical Geography, 34(6), 471-490. https://doi.org/ 10.1080/02723646.2013.855989

Serrano, E., González Trueba, J. J., Pellitero, R., González García, M., \& Gómez Lende, M. (2013). Quaternary glacial evolution in the central Cantabrian Mountains (Northern Spain). Geomorphology, 196, 65-82. https://doi.org/10.1016/j.geomorph.2012.05.001

Udden, J. (1898). Mechanical composition of wind deposits. Augustana Library Publication, 1, $1-69$.

Vieira, G. (1998). Periglacial research in the Serra da Estrela: An overview. In G. T. Vieira (Ed.), Glacial and periglacial geomorphology of the Serra da Estrela [Guidebook for the 11 fieldtrip, IGU commission on climate change and periglacial environments] (pp. 26-28). University of Lisbon.

Vieira, G. (1999). Coarse sand accumulations in granite mountains: The case-studies of the Serra do Gerês and Serra da Estrela (Portugal). Zeitschrift für Geomorphologie, 119, 105-118. 
Vieira, G. (2004). Geomorfologia dos Planaltos e Altos Vales da Serra da Estrela. Ambientes frios do Plistocénico Superior e Dinâmica Atual [Doctoral Dissertation]. University of Lisbon (p. 724).

Vieira, G. (2008). Combined numerical and geomorphological reconstruction of the Serra da Estrela plateau icefield, Portugal. Geomorphology, 97(1-2), 190-207. https://doi.org/10.1016/j. geomorph.2007.02.042

Vieira, G., Ferreira, A. B., Mycielska-Dowgiałło, E., Woronko, B., \& Olszak, I. (2001a). Thermoluminescence dating of fluvioglacial sediments (Serra da Estrela, Portugal). Proceedings of the VREQUI/I REQUI, SGP (pp. 85-88). Lisbon.

Vieira, G., Jansen, J., \& Ferreira, N. (2005). Environmental setting of the Serra da Estrela, Portugal: A short note. In T. P. Correia, R. G. Bunce, \& D. C. Howard (Eds.), Landscape ecology and management of Atlantic mountains (pp. 1-12). IALE.

Vieira, G., \& Mora, C. (1998). General characteristics of the climate of the Serra da Estrela. In G. Vieira (Ed.), Glacial and Periglacial Geomorphology of the Serra da Estrela [Guidebook for the 11 fieldtrip, IGU commission on climate change and periglacial environments] (pp. 26-28). University of Lisbon.

Vieira, G., Mycielska-Dowgiallo, E., \& Woronko, B. (2003). Sedimentological analysis of sandy-gravel accumulations, Serra da Estrela Plateaus (Portugal). Landform Analysis, 4, 99-107.

Vieira, G., \& Nieuwendam, A. (2020). Glacial and periglacial landscapes of the Serra da Estrela. In G. Vieira, J. L. Zêzere, \& C. Mora (Eds.), Landscapes and Landforms of Portugal (185-198). World Geomorphological Landscapes, Springer. https://doi.org/10.1007/978-3-319-03641-0_15

Vieira, G., \& Palacios, D. (2010, September). New cosmogenic exposure dates for the Serra da Estrela glaciation. Preliminary results. Proceedings of the national conference of geomorphology, Porto (pp. 14-25).

Wentworth, C. (1922). A scale of grades and class terms for clastic sediments. Journal of Geology, 30(5), 377-392. https://doi.org/10.1086/622910 